\title{
LEVANTAMENTO TAXONÔMICO DE CYPERUS L. 1. SUBG. ANOSPORUM (NEES) CLARKE (CYPERACEAE-CYPEREAE) NO RIO GRANDE DO SUL, BRASIL.
}

Recebido em 09.05.94. Aceito em 20.03.96.

\author{
Ana Cláudia Araujo \\ Hilda Maria Longhi-Wagner ${ }^{2}$
}

\begin{abstract}
RESUMO - (Levantamento taxonômico de Cyperus L. 1. subg. Anosporum (Nees) Clarke (Cyperaceae-Cypereae) no Rio Grande do Sul, Brasil) Este trabalho foi baseado em revisão da literatura e de herbários, coletas e observação das populações no campo. Decisões taxonômicas foram baseadas na morfologia vegetativa e reprodutiva, resultando no reconhecimento de quatorze taxa, onze espécies e três variedades. É fornecida uma chave analítica para a identifiação dos taxa encontrados, bem como descrições, ilustrações, dados de distribuição geográfica, habitat e fenologia.
\end{abstract}

Palavras chave: Florística, Cyperaceae, Cyperus subg. Anosporum, Rio Grande do Sul, Brasil.

ABSTRACT - (Taxonomic survey of Cyperus L. 1. subg. Anosporum (Nees) Clarke (CyperaceaeCypereae) in Rio Grande do Sul, Brazil). This research included a review of the literature, study of hebarium specimens, collection and observation of populations in the field. Taxonomic decisions were based on external morphology, and resulted in the recognition of fourteen taxa, eleven species and three varieties. Analytical keys for species and varietes, descriptions, illustrations and data on their geographical distribution, habitat and phenology are provided.

Key-words: Floristic, Cyperaceae, Cyperus subg. Anosporum, Rio Grande do Sul, Brazil.

\section{Introdução}

A família Cyperaceae foi dividida por Kükenthal (1936) nas subfamílias Scirpoideae, Rhynchosporoideae e Caricoideae, a primeira delas com duas tribos: Scirpeae e Cypereae. Nesta última foi aceito um único gênero, Cyperus Clarke, com seis subgêneros, entre eles Anosporum (Nees) Clarke. O subgênero Cyperus foi dividido nos grupos Choristachys e Pycnostachys. Neste último foram incluídas 16 secções,

\footnotetext{
'Núcleo de Estudos Ambientais-UNIVALI - Rua Uruguai, 458 - 88302.202-Itajaí, SC,

${ }^{2}$ Depto. Botânica-UFRGS - Av. Paulo Gama s/n - 90046.900-Porto Alegre, RS. Bolsista do CNPq.
} 
das quais três reuniam as espécies tratadas no presente trabalho: Luzuloidei, Diffusi e Haspani. Convém salientar que Pycnostachys foi considerado subgênero de Cyperus por Clarke (1893).

Barros (1960) aceitou Cyperus com sentido amplo composto por seis subgêneros, sendo Pycnostachys uma das secções do subgênero Cyperus, incluindo as espécies tratadas no presente trabalho.

A circunscrição do gênero Cyperus tem sido discutida por vários autores, ora considerado em sentido mais amplo (Kükenthal, 1936; Barros, 1960; Koyama, 1961; Engler, 1964), ora em seu sentido mais restrito (Nees, 1842; Bentham \& Hooker, 1883; Clarke, 1893; Lye, 1981; Goetghebeur, 1989).

Recentemente, Goetghebeur (1989) propôs a divisão de Cyperus em dois subgêneros, levando em conta a morfologia da inflorescência e a anatomia foliar: Cyperus, com inflorescência em espiga verdadeira ou, menos comumente, antelas congestas e tipo anatômico "Chlorocyperoide (bainha do tipo Kranz presente, caracterizando pantas C4); e Anosporum, com inflorescências monocéfalas ou antelas congestas, nunca em espigas, e tipo anatômico Eucyperoide (bainha Kranz ausente, o que caracteriza plantas C3).

Goetghebeur (1989) aceitou na sinonímia de Cyperus subg. Anosporum, Cyperus subg. Pycnostachys Clarke e Cyperus subg. Protocyperus Lye. O gênero Anosporum foi proposto por Nees (1834, apud Goetghebeur, 1989) reunindo poucas espécies caracterizadas por apresentarem estigmas trífidos e aquênios estipitados. Bentham \& Hooker (1883) aceitaram Anosporum como uma secção de Cyperus subg. Juncellus (Griseb.) Clarke. Lye (1981) tornou a aceitar Anosporum como gênero independente, constituído por 3 espécies africanas.

No presente trabalho, está sendo aceita a proposta de Goetghebeur (1989) para estabelecer a circunscrição do subgênero Anosporum. Quanto ao subgênero Cyperus, ainda necessita uma melhor avaliação em vista da inclusão no mesmo dos gêneros Mariscus e Torulinium, aceita por Goetghebeur (1989).

Se considerado sensu lato, o gênero conta com cerca de 600 espécies. Segundo a proposta mais recente de circunscrição de Cyperus (Goetghebeur, 1989) o gênero está constituído por aproximadamente 480 espécies.

Muitas espécies de Cyperus L. são conhecidas como temidas invasoras de culturas. Alguns trabalhos tem referido espécies do gênero como tendo grande interesse econômico (Reed, 1935; Metcalfe, 1971). No entanto, são poucos os estudos taxonômicos que enfocam este gênero no Brasil. Isto acarreta uma série de problemas taxonômicos e de circunscrição de grupos, os quais ainda não foram completamente resolvidos o que, consequentemente, dificulta a identificação das espécies.

Vários trabalhos citaram a ocorrência de espécies, consideradas neste trabalho dentro de Cyperus subg. Anosporum, para o Rio Grande do Sul, muitas das quais tratam-se de sinônimos (Rambo, 1949, 1954, 1956, 1959; Bertels, 1956, 1967; Barros, 1960; Teodoro Luiz, 1960; Boldrini \& Cunha, 1984). 


\section{Materiais e métodos}

Os resultados aqui apresentados foram baseados em estudos morfológicos com o auxílio de levantamento bibliográfico, coletas, observações das populações no campo e revisão de herbários.

A descrição do gênero apresentada é geral, incluindo dados da literatura. As descrições das espécies são baseadas em material sul-rio-grandense; nestas, as medidas que aparecem entre parênteses foram raramente encontradas no material. Dados da literatura, são referidos entre colchetes.

As viagens de coleta sucederam-se de dezembro a março de 1990, 1991 e 1992. O material coletado foi anexado ao Herbário do Departamento de Botânica da Universidade Federal do Rio Grande do Sul (ICN).

Dados ecológicos e de distribuição geográfica foram obtidos através da revisão de herbários e da observação das populações no campo. Foram revisados os seguintes herbários citados pela sua sigla oficial (Hohlmgren et alii, 1990): BLA, HAS, HBR, FLOR, ICN, MBM, MVFA, PACA, PEL, PKDC, R, RSPF, SP, UPCB, US.

Devido ao grande número de exsicatas analisadas, o material citado neste trabalho corresponde a exemplares selecionados para evidenciar a distribuição geográfica de cada taxon. Foram analisados os seguintes números de exemplares: Cyperus andreanus (42 exemplares); C. celluloso-reticulatus (6); C. consanguineus (35); C. eragrostis (39); C. friburgensis (21); C. haspan var. haspan (286); C. haspan var. coarctatus (18); C. incomtus (135); C. luzulae var. luzulae (152); C. luzulae var. entrerianus (60); C. reflexus var. reflexus (166); C. reflexus var. fraternus (110); C. surinamensis (86); C. virens (110).

Para análise dos dados quantitativos da descrição, foram selecionados entre 10 a 30 exemplares de cada taxon de acordo com o número de material disponível e a variabilidade do mesmo. Para cada indivíduo, foram realizadas, no mínimo, 3 medidas de cada caráter analisado.

A fim de facilitar a utilização das chaves analíticas é apresentada a figura 1, onde estão ilustrados os principais caracteres de importância taxonômica no grupo estudado.

\section{Resultados e discussão}

Cyperus L.

Cyperus L., Sp. Pl. 1 (12): 4.1753.

Lectótipo: C. esculentus L.

Plantas herbáceas, perenes, raramente anuais. Colmos trígonos ou triangulares, mais raramente cilíndricos. Folhas alternas, basilares, com lâminas lineares a lanceoladas; bainhas fechadas, lígula e antilígula ausentes. Folhas raramente reduzidas às bainhas e com lâminas vestigiais.

Inflorescência terminal ou às vezes pseudolateral, precedida por brácteas verdes dispostas espiraladamente no ápice do colmo formando um invólucro, na 
axila das quais nascem os ramos da inflorescência. Espiguetas comprimidas lateralmente, com ráquila geralmente persistente e tenaz (frágil em Torulinium), reunidas em capítulos densos a subdensos, ou apenas 2-5 espiguetas digitadas no ápice dos ramos, formando antelas ou inflorescências monocéfalas, ou ainda reunidas em espigas. Prófilo tubular fechado na base dos ramos; prófilo espicular aberto, inserido na base da ráquila, seguido pela gluma bracteóide estéril. Glumas férteis com disposição alterno-dística ao longo da ráquila. Flores monoclinas, nas axilas das glumas, perigônio ausente. Estames 1-3. Estigmas 3. Aquênio trígono ou triangular. (Figura 1).

O gênero Cyperus sensu Goetghebeur (1989) inclui cerca de 480 espécies divididas em dois subgêneros, distribuídas em zonas tropicais e subtropicais, chegando até áreas temperadas.

Neste trabalho, conforme já salientado, foi aceita a divisão de Cyperus nos subgêneros Cyperus e Anosporum, conforme proposta de Goetghebeur (1989), baseada em Chemerzon (1937, apud Goetghebeur, 1989), que leva em conta especialmente a anatomia foliar. O primeiro subgênero corresponde ao tipo anatômico "Chlorocyperoide" e o segundo ao tipo anatômico "Eucyperoide".

O tipo "Chlorocyperoide" ocorre em espécies com fotossíntese $\mathrm{C}_{4}$ que apresentam bainha vascular do tipo Kranz. Além disso, caracteriza-se pela presença de hipoderme na face adaxial da lâmina foliar, clorênquima radiado em torno dos feixes vasculares, e presença de duas bainhas envolvendo os feixes, a do tipo Kranz, parenquimática e mais interna, e a mestomática, esclerenquimática e mais externa.

O tipo "Eucyperoide" ocorre nas espécies do subgênero Anosporum com fotossíntese do tipo $\mathrm{C}_{3}$, também com bainha dupla, mas sem anatomia Kranz, como será adiante descrito.

\section{Chave para os subgêneros de Cyperus}

1. Anatomia foliar Chlorocyperoide (Kranz). Espiguetas, mais comumente, dispostas em espigas verdadeiras ou, às vezes, em umbelas congestas no ápice dos ramos Cyperus

1'. Anatomia foliar Eucyperoide (não-Kranz). Espiguetas reunidas em inflorescências digitadas, pseudo-digitadas ou capítulos no ápice dos ramos, formando antelas ou inflorescências monocéfalas, nunca espigas verdadeiras ......Anosporum

Cyperus subg. Anosporum (Nees) Clarke Cyperus subg. Anosporum (Nees) Clarke, J. Linn. Soc. Bot. 21: 33, 34, 25. 1884. Anosporum Nees, Linnaea 9: 287. 1834. Espécie tipo: Anosporum monocephalum (Roxburger) Nees (=Cyperus cephalotes Vahl).

Ervas perenes, 20-120 (145) $\mathrm{cm}$ de altura, rizomatosas ou cespitosas. Colmos trígonos, triangulares ou mais raro cilíndricos, lisos, raramente escabros. Folhas basilares, raramente reduzidas às bainhas, com lâminas lineares a linear- lanceoladas, 

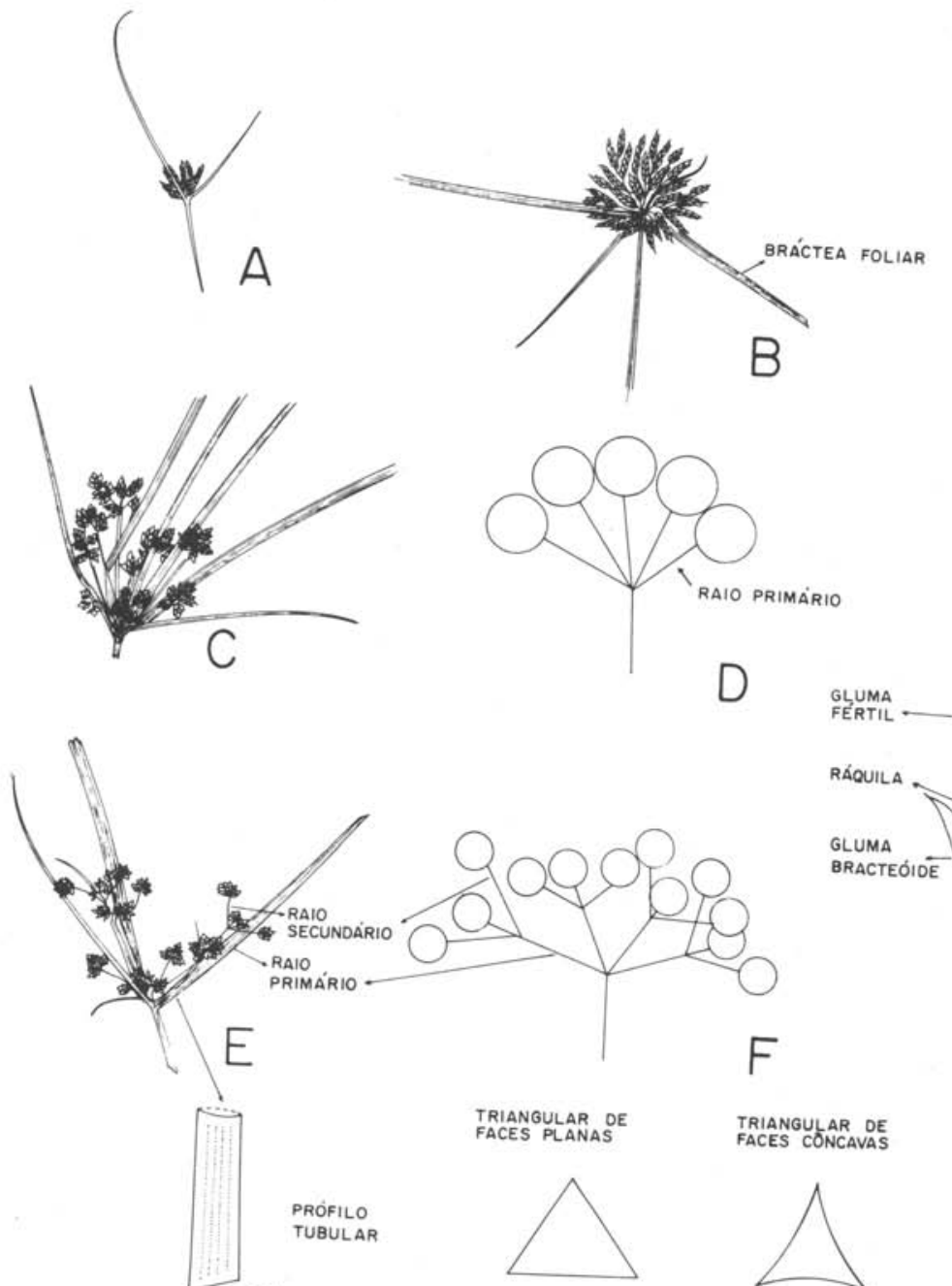

FACES PLANAS

TRIANGULAR DE
FACES CONCAVAS

TRIGONO

PRÓFILO

TUBULAR
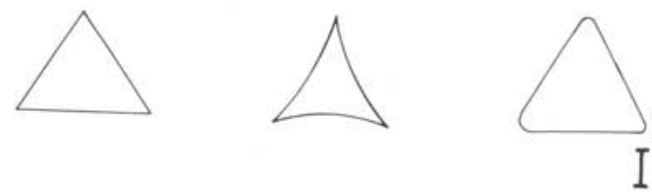

Figura 1. Prancha esquemática de ilustraçōes de importância taxonômica.

A: inflorescência monocéfala capituliforme (Longhi-Wagner 2033 - ICN); B: inflorescência monocéfala com espiguetas reunidas em glomérulo (Longhi-Wagner \& A. C. Araújo et al. 2380 - ICN); C: inflorescência em umbela simples (Longhi-Wagner \& A. C. Araújo 2432 - ICN); D: desenho esquemático de umbela simples; E: inflorescência um umbela composta (Longhi-Wagner \& A. C. Araújo 2245 - ICN); F: desenho esquemático de inflorescência em umbela composta; G: prófilo tubular; H: espigueta (Cyperus andreanus M. Sobral 5959 - ICN); I: secções transversais dos aquênios de Cyperus subg. Anosporum. 
geralmente escabras nas margens e na nervura central; bainhas fechadas, tênues no ápice da margem interna.

Inflorescência terminal, em antela simples ou composta, ou formando estruturas monocéfalas. Prófilo tubular de ápice agudo ou arredondado, raramente bidentado. Prófilo espicular alterno à gluma bracteóide, obtuso ou agudo. Espiguetas plurifloras, reunidas em capítulos, glomérulos ou pseudo-digitadas no ápice dos ramos, ráquila tenaz, com articulação abaixo do prófilo e da gluma bracteóide. Glumas férteis com 35 nervuras no dorso, ápice arredondado, agudo ou mais raramente mucronado, dispostas disticamente ao longo da ráquila. Flores monoclinas, nas axilas das glumas. Estames 3, ou 1-2 na mesma inflorescência, ou apenas 1 (C. reflexus); anteras basifixas, conectivo rostrado ou não. Estigmas 3. Aquênio trígono ou triangular, elíptico, ovado ou obovado, geralmente castanho, superfície lustrosa, comumente pontuada.

\section{Chave para a taxa de Cyperus subgen. Anosporun (Nees) Clarke no Rio Grande do Sul.}

\section{Inflorescências monocéfalas.}

2. Inflorescências capituliformes, glumas férteis esverdeadas 8. C. incomtus

2'. Inflorescências em glomérulos com espiguetas densamente agrupadas. Glumas férteis amareladas, avermelhadas ou violáceas.

3. Estames 3, conectivo rostrado, com ápice estrelado.Plantas geralmente áfilas 7.C. haspan var. coarctatus

3'. Estame 1, conectivo não rostrado. Plantas providas de lâminas foliares

11. C. reflexus var. reflexus

1'. Inflorescências em antelas simples ou compostas.

4. Antelas compostas.

\section{Colmo escabro}

6. Colmos escabros nas faces ou nos ângulos. Aquênios rugosos de 0,6-0,8 mm de comprimento 13. C. surinamensis

6'. Colmos escabros só nos ângulos. Aquênios lisos de 1,2 a 1,4 mm de comprimento. 14. C. virens

5'. Colmos lisos

7. Espiguetas reunidas em glomérulos densos no ápice dos ramos 10. C. luzulae var. entrerianus

7'. Espiguetas laxamente digitadas no ápice dos ramos.

8. Estames 1-2. Glumas amarelo-alaranjadas ou esverdeadas.

9. Estames 2. Glumas amarelo-alaranjadas, bem imbricadas.

Lâminas foliares papiráceas quando maduras.

2. C. celluloso-reticulatus

9'. Estames 1. Glumas esverdeadas, laxamente imbricadas. Lâminas foliares coriáceas 5. C. friburgensis

8'. Estames 3. Glumas férteis avermelhadas ou violáceas.

10. Aquênios pálidos, ovados e trigonos 
10’. Aquênios castanhos, elípticos e triangulars de faces côncavas 1. C. andreanus

4'. Antela simples (raramente ramos primários com divisões secundárias:C. eragrostis, $C$. luzulae var. luzulae e C.reflexus var. fraternus ).

11. Colmos escabros.

12. Colmos escabros nos ângulos e nas faces. Aquênios $0,6-0,8 \mathrm{~mm}$ de comprimento, castanho-claros a avermelhados

13. C. surinamensis

12'. Colmos escabros nos ângulos ou, mais raramente, apenas em um deles. Aquênios 1,2-1,4 mm de comprimento, casta nho-escuros 14. C. virens 11'. Colmos lisos.

13. Aquênio com base estipitada

13'. Aquênio sem estípite na base. Espigueta de 2-6(8) mm de comprimento

14. Glumas férteis avermelhadas, alaranjadas ou violáceas.

15. Aquênios elípticos, de ápice apiculado. Colmos cilíndricos, ou obscuramente trígonos na base e claramente trígonos no ápice....12. C.reflexus var. fraternus

15'. Aquênios estreitamente elípticos, de ápice atenuado. Colmos claramente trígonos em todo comprimento 3. C. consanguineus

14'. Glumas férteis esverdeadas a amareladas 9. C. luzulae var. luzulae

\section{Descrição dos taxa}

\section{Cyperus andreanus Maury (Figuras 2,8)}

C. andreanus Maury, Morot J. Bot. 2: 392. 1888. Tipo: Equador, Tambo de Sabanilla, André 365 (K, NY, frag. C).

Perene, (27) 50-90 cm de altura, cespitosa, com rizomas curtos. Colmos (1,5) 2$3 \mathrm{~mm}$ de largura, trígonos, lisos. Folhas (4)6-10 por colmo; bainhas (2) 6-11 (14) cm de comprimento, violáceas, tênues no ápice da margem interna; lâminas (7) 30-60 (75) $\mathrm{cm}$ de comprimento, (4) 7-10 mm de largura, linear-lanceoladas, opacas, margens escabras.

Inflorescência em antela composta, laxa, (5) 7-11 cm de comprimento, 7-9 (20) cm de largura, 7-8 (10) raios primários de $(3,5)$ 6-9 (14) cm de comprimento, raios secundários 1,5-2 (4) $\mathrm{cm}$ de comprimento, com espiguetas laxamente digitadas no ápice. Brácteas involucrais 5-7 (9), a inferior (8) 25-35 (70) cm de comprimento, 4-8 (12) $\mathrm{mm}$ de largura, escabras nas margens e nervura central, superfície lisa. Prófilo tubular $(4,5)$ 11-15 mm de comprimento, membranáceo, avermelhado a violáceo, 
ápice agudo a subagudo; prófilo espicular 1,2-2 (3) mm de comprimento, (0,4) 0,6-1,1 $\mathrm{mm}$ de largura, ápice obtuso a subagudo. Espiguetas (5) 9- 13 (22) mm de comprimento, (2) 2,5-4 mm de largura, lanceoladas, (8) 11-20 (28)-floras; glumas (1,5) 2,4-4 mm de comprimento, 0,7- 1,2 mm de largura, lanceoladas, ápice agudo, laxamente imbricadas, avermelhadas, superfície lisa, carena trinervada, esverdeada, lisa. Estames 3, conectivo rostrado com o ápice agudo. Aquênios 1,2-1,8 mm de comprimento, 0,5-0,8 mm de largura, elípticos, triangulares de faces côncavas, castanhos, superfície pontuada, brilhante, ápice apiculado, apículo de $0,1 \mathrm{~mm}$.

Habitat: campos úmidos, sobre pedras em locais úmidos, e em beira de estrada.

Distribuição geográfica: Brasil, Argentina e Guiana Francesa. Também foi citada para a Bolívia, Equador e Paraguai.

Fenologia: floresce e frutifica de outubro a abril. Em outras regiões do País a espécie permanece florescendo nos demais meses do ano.

\section{Material examinado}

BRASIL - RIO GRANDE DO SUL: Canela, Caracol, 28 dez. 1972, P. Pellizzaro et alii s.n.(ICN 21820); Cerro Largo, out. 1944, E. Frederichs s.n. (PACA 26788); Farroupilha, 25 nov. 1957, O. Camargo 2663 (PACA); Faxinal do Soturno, Cerro Comprido, s.d., M. Sobral 5959 (ICN); São Francisco de Paula, Aratinga, dez. 1984, M. Sobral 3230 (ICN); Tenente Portela, Parque Estadual do Turvo, P. Brack 1374 (ICN).

2. Cyperus celluloso-reticulatus Boeckeler (Figuras 3,8)

C. celluloso-reticulatus Boeckeler, Allg. Bot. Zeitschr. Syst. 1: 202. 1895. Tipo: Brasil, Santa Catarina, Tubarão, Ule 1332 (não localizado).

Perene, $70-110 \mathrm{~cm}$ de altura, cespitosa, com rizomas curtos. Colmos $(3,5) 6-8$ $\mathrm{mm}$ de largura, triangulares de faces retas, lisos. Folhas (3) 9-12 por colmo; bainhas 11-13 cm de comprimento, violáceas, tênues no ápice da margem interna; lâminas 5080 (90) cm de comprimento, (10) 15-20 mm de largura, linear-lanceoladas, marcadamente reticuladas e brilhantes, margens escabras, caracteristicamente papiráceas quando velhas.

Inflorescência em antela composta, laxa, 9-11 (15) cm de comprimento, (8) 15-20 cm de largura, com 8-10 (15) raios primários de 6-10 $\mathrm{cm}$ de comprimento, raios secundários 1-1,5 (2) cm de comprimento, com espiguetas digitadas no ápice. Brácteas involucrais 5-8 (10), a inferior 40-70 cm de comprimento, 10-12 (16) mm de largura, escabras nas margens e nervura central, superfície marcadamente reticulada. Prófilo tubular 2,5-4 mm de comprimento, membranáceo, violáceo, ápice agudo, às vezes bidentado; prófilo espicular 1,2-1,5 (2) mm de comprimento, 0,60,8 (1) mm de largura, ápice obtuso a agudo. Espiguetas (5) 7-12 (20) $\mathrm{mm} \mathrm{de}$ comprimento, (2) 3-4 mm de largura, oblongo- lanceoladas, (10) 20-30 (50)-floras; glumas 1,5-2 mm de comprimento, $(0,8) 1-1,2(1,5) \mathrm{mm}$ de largura, ovadas, ápice 


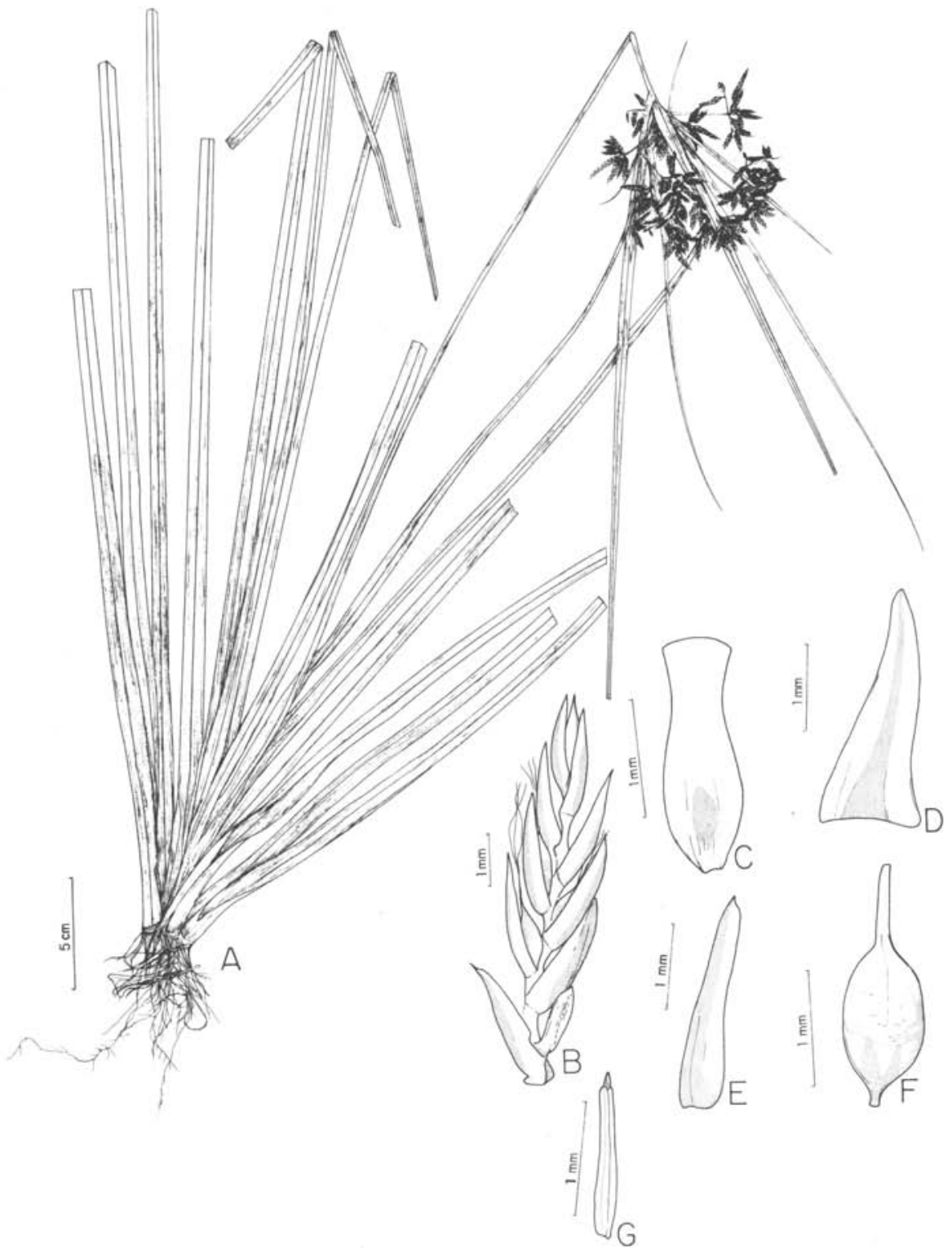

Figura 2. Cyperus andreanus (M. Sobral 5959 - ICN)

A: hábito; B: espigueta com gluma bracteóide e prófilo espicular presentes; C: prófilo espicular; D: gluma bracteóide; E: gluma fértil; F: fruto, com base do estigma persistente indiferenciada do fruto; G: antera. 
mucronado, bem imbricadas, amarelo-alaranjadas, superfície marcadamente reticulada, carena trinervada, esverdeada, lisa. Estames 2, conectivo rostrado com o ápice agudo. Aquênios 1,1-1,4 mm de comprimento, 0,6-0,8 mm de largura, ovados, trígonos, com uma face maior do que as demais, pálidos, superfície pontuadorugosa, aderente, brilhante, ápice obtuso.

Habitat: banhados turfosos e locais úmidos, em solos areno- argilosos ou argilosos. Distribuição geográfica: Brasil.

Fenologia: floresce e frutifica entre os meses de novembro e março.

\section{Material examinado}

BRASIL - RIO GRANDE DO SUL: Torres, Parque de Torres, 11 jul. 1972, L. Baptista \& M.L. Lorscheitter s.n. (ICN 28193), Itapeva, 20 fev. 1975, O. Camargos.n. (HAS 50955), próximo à lagoa Itapeva, 17 fev. 1992, Longhi-Wagner \& A.C. Araujo 2506, 2511 (ICN).

\section{Cyperus consanguineus Kunth (Figuras 4, 8)}

C. consanguineus Kunth, Enum. Pl. 2: 1837. Tipo: Brasil, Sellow 11227 (Foto do holótipo US!).

Perene, (30) 90-120 cm de altura, rizomatosa, rizomas curtos. Colmos $(1,5) 4$ $5 \mathrm{~mm}$ de largura, trígonos, lisos. Folhas 4-6 por colmo; bainhas (6) $10-18 \mathrm{~cm}$ de comprimento, violáceas, tênues no ápice da margem interna; lâminas (30) $60-75 \mathrm{~cm}$ de comprimento, $(3,5)$ 8-11 mm de largura, linear-lanceoladas, coriáceas, reticuladas e brilhantes, margens lisas.

Inflorescência em antela simples, contraída, $4-5 \mathrm{~cm}$ de comprimento, $3,6 \mathrm{~cm}$ de largura, com 5-6 raios primários de 2-3 (4) $\mathrm{cm}$ de comprimento, espiguetas reunidas em glomérulos no ápice. Brácteas involucrais $4-5$, a inferior $25-50 \mathrm{~cm}$ de comprimento, 3,5-6 (8) $\mathrm{mm}$ de largura, margens levemente escabras, superfície finamente reticulada. Prófilo tubular $10 \mathrm{~mm}$ de comprimento, membranáceo, violáceo, ápice caudado; prófilo espicular $(0,6)$ 0,8-1,1 mm de comprimento, 0,3-0,4 $(0,9) \mathrm{mm}$ de largura, ápice subagudo. Espiguetas (1,5) 2,5-4 mm de comprimento, (1) 2,5-4 mm de largura, ovadas, 4-7 (9)-floras; glumas (1,2) 2,5-3,5 mm de comprimento, 0,6-1,2 mm de largura, lineares, ápice obtuso a arredondado, fortemente imbricadas, avermelhadas ou violáceas, superfície brilhante, carena trinervada, esverdeada ou avermelhada, lisa. Estames 2, conectivo rostrado com o ápice agudo. Aquênios (1) $2 \mathrm{~mm}$ de comprimento, 0,2-0,3 mm de largura, estreitamente elípticos, trígonos, negros, superfície pontuada, brilhante, ápice atenuado.

Habitat: campos úmidos e margem de banhados.

Distribuição geográfica: Brasil, Argentina e Venezuela.

Fenologia: floresce e frutifica entre novembro e fevereiro. Uma única coleta foi registrada para o mês de julho, apresentando inflorescência jovem. Em outros estados do Brasil, há registro de coletas também para os meses de maio e agosto. 


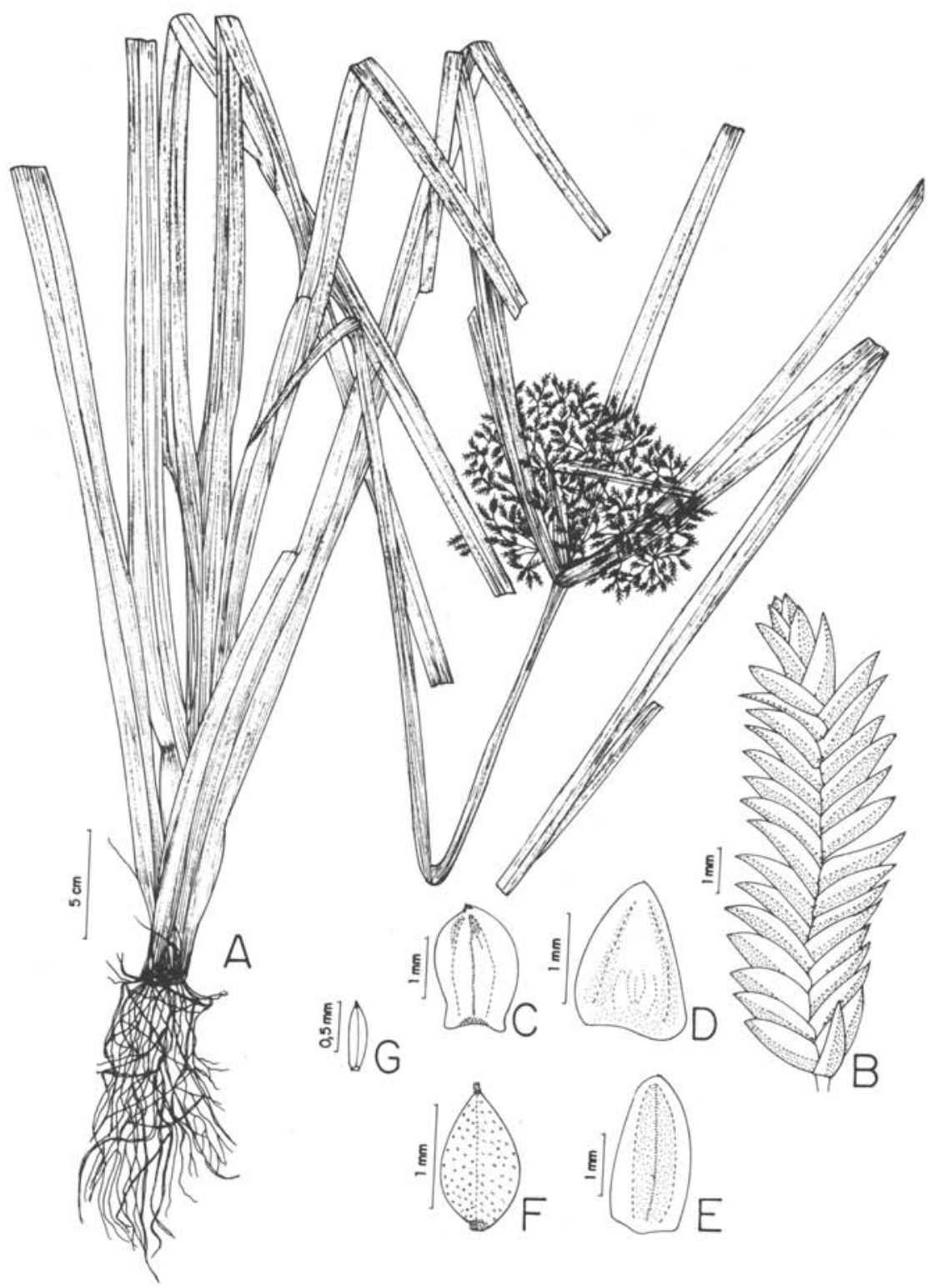

Figuras 3. Cyperus celluloso - reticulatus (Longhi-Wagner \& A. C. Araújo 2506 - ICN). A: hábito; B: espigueta com gluma bracteóide na base; C: prófilo espicular; D: gluma bracteóide; E: gluma fértil; Fifruto, com base do estigma persistente diferenciada do fruto; G: antera. 


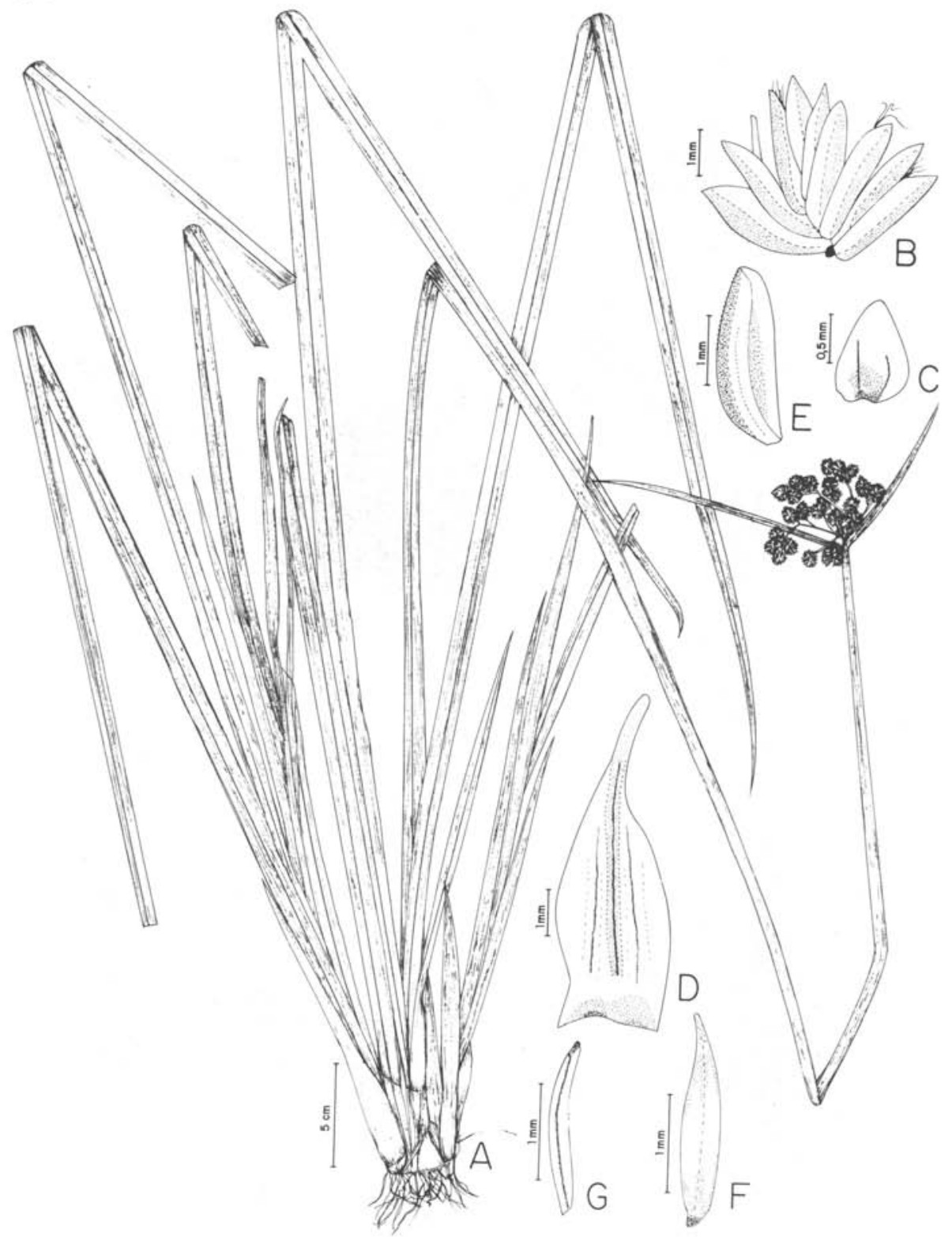

Figura 4. Cyperus consanguineus (B. Irgang et al. s. n. - ICN 28194)

A: hábito; B: espigueta, prófilo espicular e gluma bracteóide retirados; C: prófilo espicular; D: gluma bracteóide; E: gluma fértil com carena escabra; F: fruto, com ápice atenuado; G: antera. 


\section{Material examinado}

BRASIL - RIO GRANDE DO SUL: Santa Maria, Estação Experimental de Silvicultura, s.d., O. Camargo 138 (PACA); Tapes, 15 mar. 1985, Nhuch s.n.(ICN 83083); Tenente Portela, Parque Estadual do Turvo, s.d., P. Brack 1290 (ICN); Torres, Parque de Torres, 14 jul. 1972, B. Irgang et alii s.n. (ICN 28194).

\section{Cyperus eragrostis Lam. (Figuras 5, 9)}

C. eragrostis Lam., Tabl. Encycl. 1: 146. 1791. Tipo: América Meridional (não localizado).

Perene, (18) 30-90 cm de altura, densamente cespitosa, com rizomas muito curtos. Colmos $(1,2)$ 2-5 mm de largura, geralmente trígonos, às vezes triangulares, lisos, raramente escabros nos ângulos, com base lenhosa. Folhas 3-5 por colmo; bainhas 5-7 (10) cm de comprimento, rosadas a violáceas, raramente amareladas, tênues no ápice da margem interna; lâminas (20) 30-50 (70) cm de comprimento, (3) 5-8 (11) mm de largura, lanceoladas, coriáceas, reticuladas, margens lisas ou raramente escabras.

Inflorescência em antela simples, pouco contraída, (3) 5-8 (15) cm de comprimento, 5-10 (14) cm de largura, com 5-7 (11) raios primários de $3-7$ (11) cm de comprimento, espiguetas reunidas em glomérulos no ápice, raios secundários raramente presentes. Brácteas involucrais 5-7, a inferior (15) $25-50 \mathrm{~cm}$ de comprimento, (3) 5-9 mm de largura, margens escabras, superfície reticulada. Prófilo tubular (3) 7 10 (13) $\mathrm{mm}$ de comprimento, membranáceo, amarelado, raramente rosado, ápice subagudo a agudo, às vezes arredondado; prófilo espicular 0,8-1,2 $(1,6) \mathrm{mm}$ de comprimento, $(0,5) 0,6-0,8(1) \mathrm{mm}$ de largura, ápice arredondado, às vezes truncado. Espiguetas (6) 8-10 (14) $\mathrm{mm}$ de comprimento, (2) 2,5-4 mm de largura, ovadolanceoladas a oblongas, (8) 10-20 (35)-floras; glumas (1,2) 2-2,5 mm de comprimento, 0,8-1,2 $(1,4) \mathrm{mm}$ de largura, ovado-naviculares, ápice arredondado, laxamente imbricadas, esverdeadas a amareladas, raras vezes avermelhadas, reticuladas, carena trinervada, esverdeada e lisa. Estame 1, conectivo rostrado, com o ápice agudo. Aquênios (1) 1,3-1,4 mm de comprimento, $(0,4)$ 0,5-0,6 (0,7) mm de largura, oblongos, marcadamente triangulares de faces côncavas, castanho- ferrugíneos a negros quando maduros, superfície lustrosa e reticulada, ápice simetricamente apiculado e base estipitada, ambos negros.

Habitat: ocorre em campos úmidos ou secos, banhados periodicamente secos e áreas permanentemente alagadas. Pode ocorrer em locais alterados como gramados, aterros e beira de estrada. Desenvolve-se principalmente em solos arenosos ou areno- argilosos.

Distribuição geográfica: Brasil e Argentina. Há citações para a África, Bolívia, Chile, Estados Unidos, Índia, México e Peru.

Fenologia: floresce e frutifica entre outubro e abril. Em regiões mais quentes do Brasil 


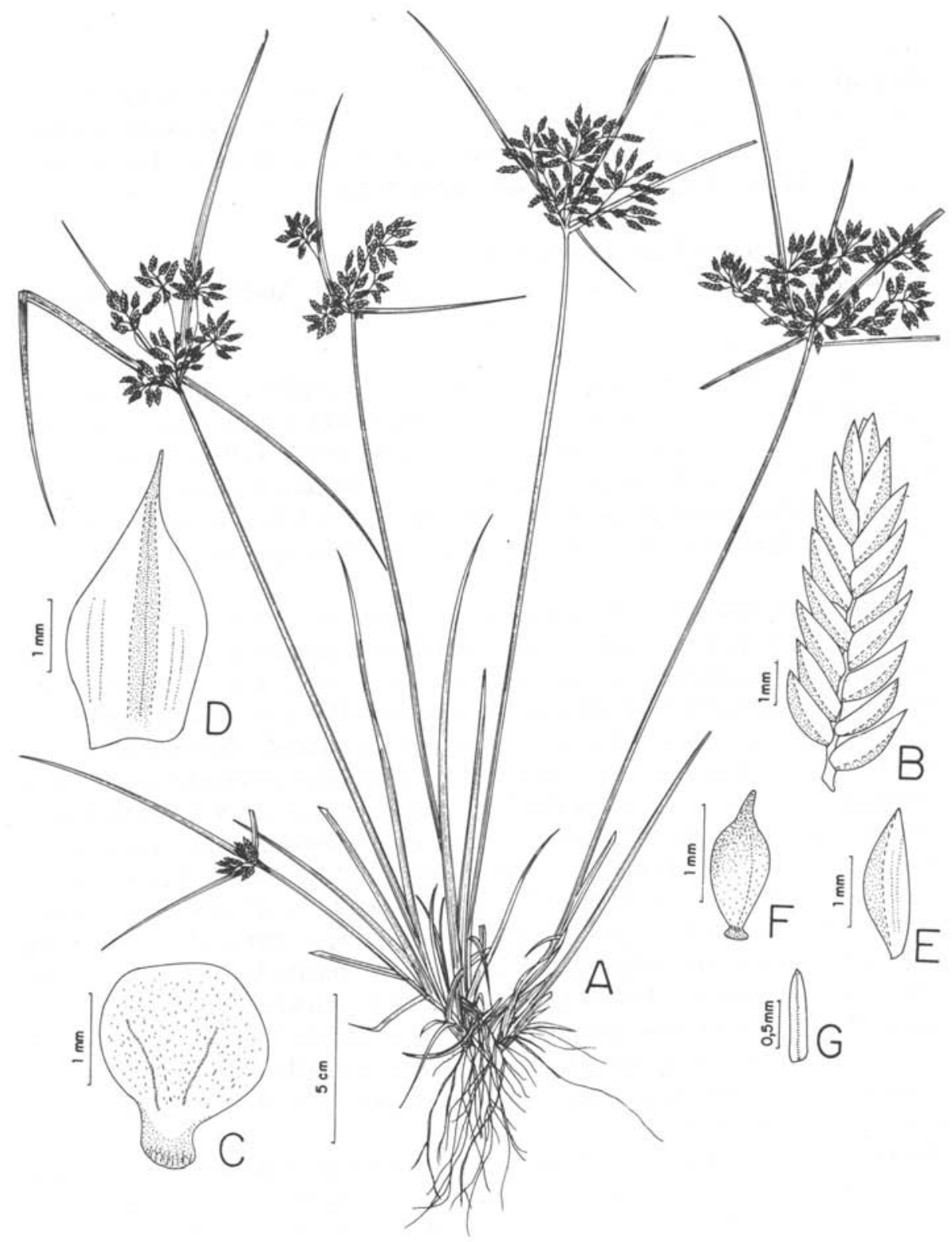

Figura 5. Cyperus eragrostis (Longhi-Wagner, A. C. Araújo et al. 2446 - ICN)

A: hábito; B: espigueta, prófilo espicular e gluma bracteóide retirados; C: prófilo espicular; D: gluma bracteóide; E: gluma fértil; F: fruto, com base estipitada; G: antera. 


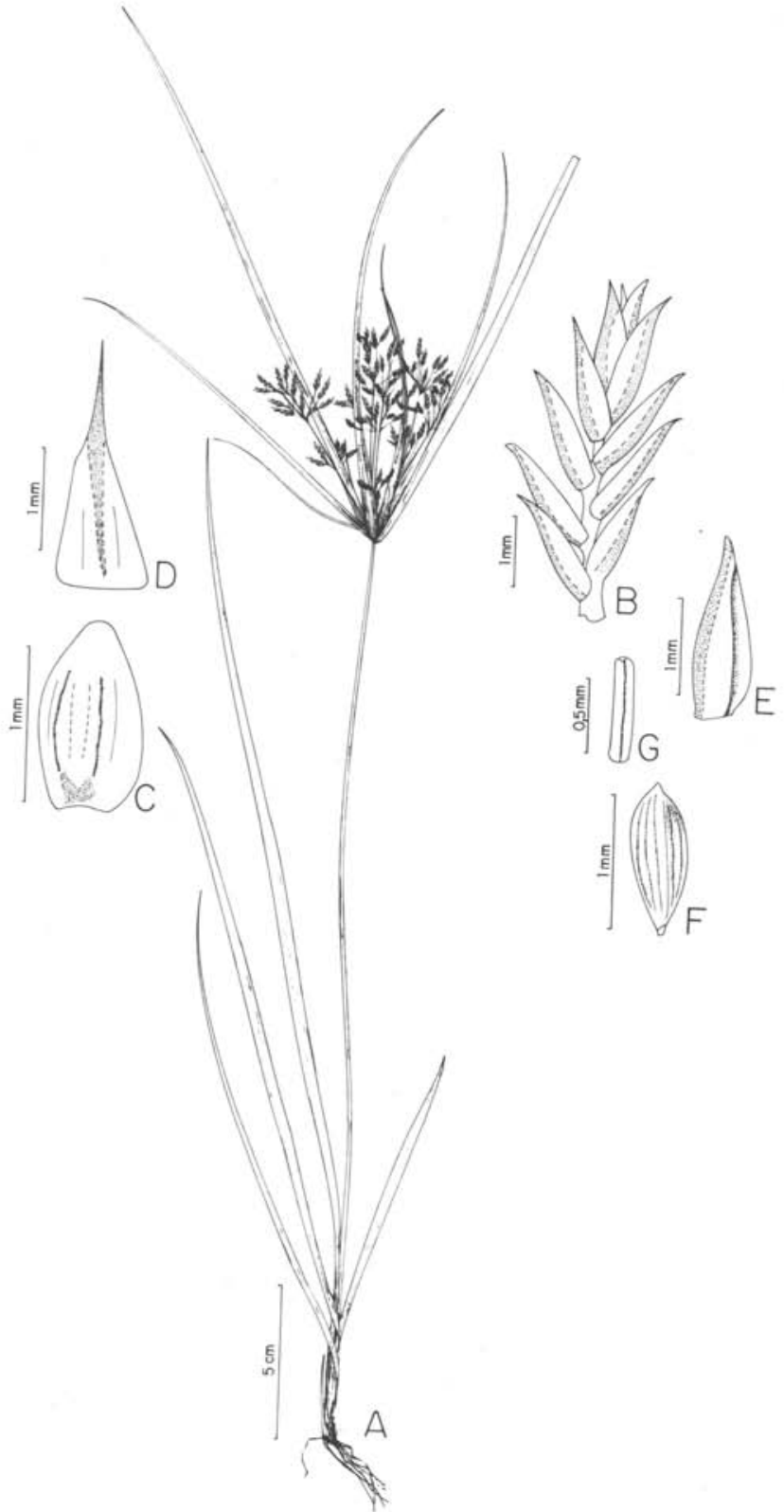

Figura 6. Cyperus friburgensis (Bassan 709 - Has)

A: hábito; B: espigueta, prófilo espicular e gluma bracteóide retirados; C: prófilo espicular; D: gluma bracteóide; E: gluma fértil; F: fruto; G: antera. 
foi encontrada florescida nos meses de maio, junho e agosto.

\section{Material examinado}

BRASIL - RIO GRANDE DO SUL: Alegrete, BR 290, 7 jan. 1991, Longhi-Wagner \& A.C. Araujo 2413 (ICN); Passo Fundo, Vila Annes, 14 mar. 1980, B. Severo \& $R$. Werlang 516 (RSPF); Pelotas, 15 dez. 1953, Bertels 1051 (PACA); Porto Alegre, 26 de nov. 1990.Longhi-Wagner 2129 (ICN), Praia de Belas, 14 abr. 1967,A.G. Ferreira 164 (ICN); Rio Grande, Cassino, 6 abr. 1991, Longhi-Wagner, A.C. Araujo et alii 2510 (ICN); Venâncio Aires, s.d., Ir. Augusto 153 (MVFA).

\section{Cyperus friburgensis Boeckeler (Figuras 6, 9)}

C. friburgensis Boeckeler, Cyp. Novae 2: 2. 1890. Tipo: Brasil, Rio de Janeiro, Nova Friburgo (não localizado).

C. fusco-ferrugineus Boeckeler, Allg. Bot. Zeitschr. Syst. 1: 226. 1895. Tipo: Brasil, Rio de Janeiro, Nova Friburgo, Mendonça 909 (Holótipo B !).

Perene, 40 [90] cm de altura, cespitosa, com rizomas curtos. Colmos 2,2 [3] $\mathrm{mm}$ de largura, trígonos, lisos. Folhas 4 por colmo; bainhas $4,5 \mathrm{~cm}$ de comprimento, violáceas, tênues no ápice da margem interna; lâminas $35-43 \mathrm{~cm}$ de comprimento, 2,8 [6- 10] mm de largura, linear-lanceoladas, coriáceas, opacas, escabras nas margens e nervura central.

Inflorescência em antela composta, laxa, $11 \mathrm{~cm}$ de comprimento, $6 \mathrm{~cm}$ de largura, com 6 [10-14] raios primários de 5- 7 [15-18] $\mathrm{cm}$ de comprimento, raios secundários $1,5[5] \mathrm{cm}$ de comprimento, com espiguetas digitadas no ápice. Brácteas involucrais 6 [7-14], a inferior [20-30] $\mathrm{cm}$ de comprimento, 4,3 $\mathrm{mm}$ de largura, margens e nervuras lisas, raramente escabras, superfície lisa. Prófilo tubular $5 \mathrm{~mm}$ de comprimento, membranáceo, esverdeado, ápice agudo; prófilo espicular 1,0 $\mathrm{mm}$ de comprimento, 0,6 mm de largura, ápice arredondado. Espiguetas 4,6 [6-10] mm de comprimento, 2,4 [2] mm de largura, ovadas, 8-10 [10-19]-floras; glumas 1,8-2,0 $[2,5] \mathrm{mm}$ de comprimento, $0,6-0,8 \mathrm{~mm}$ de largura, ovado-lanceoladas, ápice agudo à caudado, laxamente imbricadas, esverdeadas, brilhantes, carena trinervada, esverdeada e lisa. Estame 1, conectivo rostrado com o ápice obtuso. Aquênios 0,8-0,9 [2] mm de comprimento, $0,4[0,6] \mathrm{mm}$ de largura, oblongos, triangulares, pálidos [castanhos], estriados longitudinalmente, ápice obtuso [mucronado], estípete ausente,

Habitat: beira de mata, locais sombreados.

Distribuição geográfica: Brasil e Argentina. A literatura cita para a Bolívia, Paraguai, Peru e Venezuela.

Fenologia: o único exemplar coletado no Estado é registrado para o mês de fevereiro. Nas demais regiões do Brasil floresce principalmente entre os meses de novembro a março, havendo registros também para os meses de abril e julho.

BRASIL - RIO GRANDE DO SUL: Liberato Salzano, Reserva Indígena, 5 dez. 1986, 
6. Cyperus haspan L. var. haspan (Figuras 7 A-G, 11)

C. haspan L., Sp. Pl. I: 45. 1753. Tipo: India, Hermann (BM).

C. efoliatus Boeckeler, Allg. Bot. Zeitschr. 1: 226. 1895. Tipo: Costa Rica, Cartago:

Turrialba, set. 1893, Tonduz 8304 (isótipo US!).

Perene, (15) 30-50 (70) $\mathrm{cm}$ de altura, com rizomas curtos, ligando colmos isolados. Colmos (1,5) 2-3,5 mm de largura, flácidos, triangulares de faces côncavas, lisos. Folhas 1 (2) por colmo, lâminas geralmente presentes; bainhas, quando as lâminas estão presentes, (3) 5-8 (13) cm de comprimento, quando lâminas ausentes, (6) 7-15 (19) cm de comprimento, violáceas, tênues no ápice da margem interna; lâminas (8) 17-29 cm de comprimento, (1) 1,5-2,5 mm de largura, linear-lanceoladas, coriáceas, geralmente lisas nas margens, brilhantes ao longo da nervura central.

Inflorescência em antela composta, laxa, (2) $5-8 \mathrm{~cm}$ de comprimento, (1,5) 3-7 $\mathrm{cm}$ de largura, com (5) 7-12 raios primários de $2-5(8) \mathrm{cm}$ de comprimento, raios secundários 1-2 (3) $\mathrm{cm}$ de comprimento com 3-5 espiguetas digitadas no ápice. Brácteas involucrais (1) 2, a inferior (3) $5-11$ (13) cm de comprimento, 1,5-3 (4) $\mathrm{mm}$ de largura, margens e nervura central lisas, superfície lisa. Prófilo tubular 2,5-4 (8) mm de comprimento, membranáceo, rosado ou avermelhado, ápice bidentado; prófilo espicular 0,8-1 (1,1) $\mathrm{mm}$ de comprimento, 0,5-0,6 $\mathrm{mm}$ de largura, alaranjado ou avermelhado, ápice subagudo ou truncado. Espiguetas (2) 4-8 (10) mm de comprimento, $(0,8) 1-1,4(1,8)$ mm de largura, lanceoladas, (5) 10-30-floras; glumas $(0,6) 1-1,7$ $\mathrm{mm}$ de comprimento, $(0,4)$ 0,6-0,9 mm de largura, ovadas, ápice mucronado, laxa a fortemente imbricadas, avermelhadas ou violáceas, brilhantes, carena trinervada, esverdeada e lisa. Estames 3, conectivo rostrado com ápice estrelado, branco e brilhante. Aquênios 0,4-0,6 mm de comprimento, $(0,2)$ 0,3-0,4 mm de largura, ovados, trígonos, pálidos, superfície pontuada e brilhante, ápice obtuso, estípete ausente.

Habitat: ocorre em campos e baixadas úmidas, banhados turfosos e margens de lagoas, sempre associada a ambientes úmidos ou alagados.

Distribuição geográfica: Brasil, Argentina, Equador, Guiana Inglesa, Paraguai, Rodésia, Suriname, Uruguai e Venezuela. Foi citada também para a Coréia, Costa Rica, Cuba, Estados Unidos, Guatemala, Honduras, Japão, Madagascar, México, Moçambique e Nicarágua.

Fenologia: floresce e frutifica predominantemente durante os meses de novembro a abril. No entanto, há coletas de material fértil no mês de julho, com inflorescências jovens. Nas demais regiões do Brasil a espécie apresenta período mais longo de florescimento.

Comentários

Cyperus haspan é uma espécie vegetativamente bastante homogênea, caracterizada por colmos bastante frágeis de secção triangular de faces côncavas. Entretanto, 


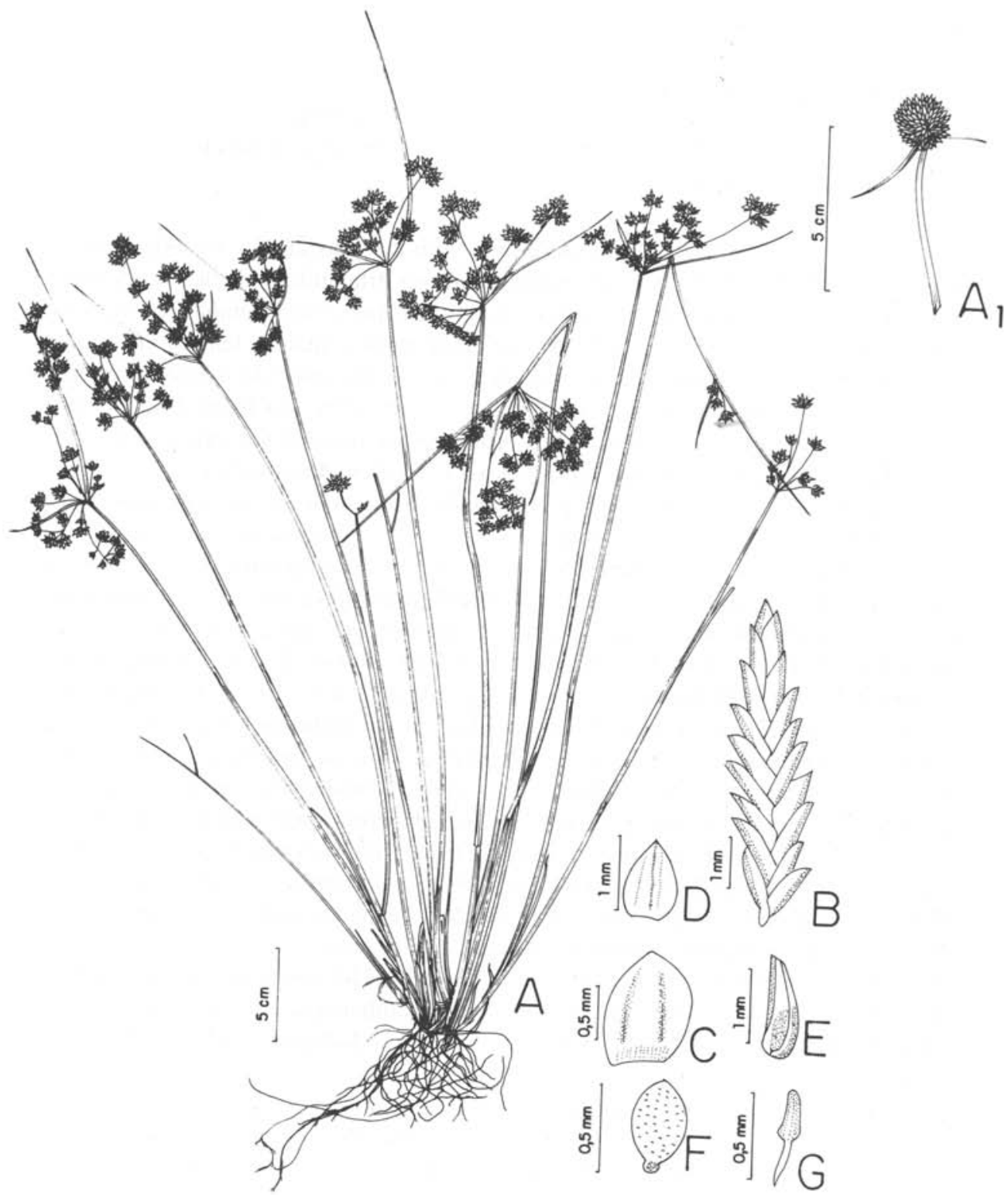

Figura 7. Cyperus haspan var. haspan (Longhi-Wagner \& A. C. Araujo 23.35 - ICN) A: hábito; B: espigueta, prófilo espicular e gluma bacteóide retirados; C: prófilo espicular; D: gluma bracteóide; E: gluma fértil; F: fruto; G: estame.

$\mathrm{A}_{1}$ : inflorescência de Cyperus haspan var. coarctatus (Longhi-Wagner \& A. C. Araújo 2009 - ICN). 


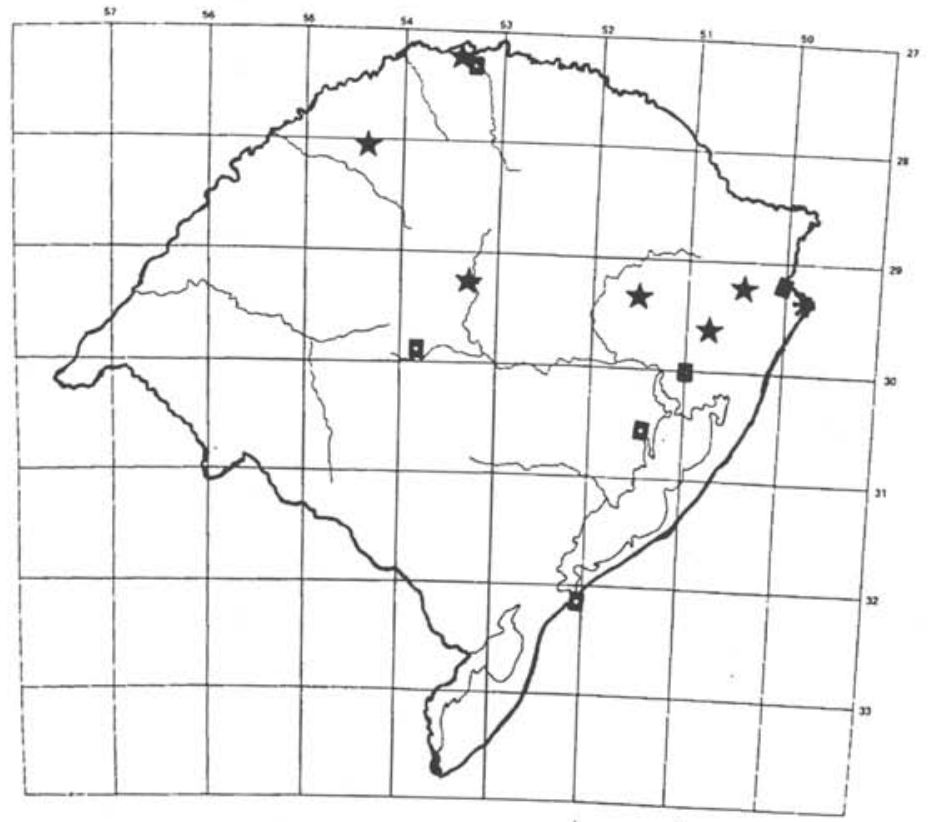
Figura 8. Distribuição de C. andreanus ( $\star$ ), C. celluloso reticulatus ( ) e C. consanguineus ( $*$ ) no
Rio Grande do Sul

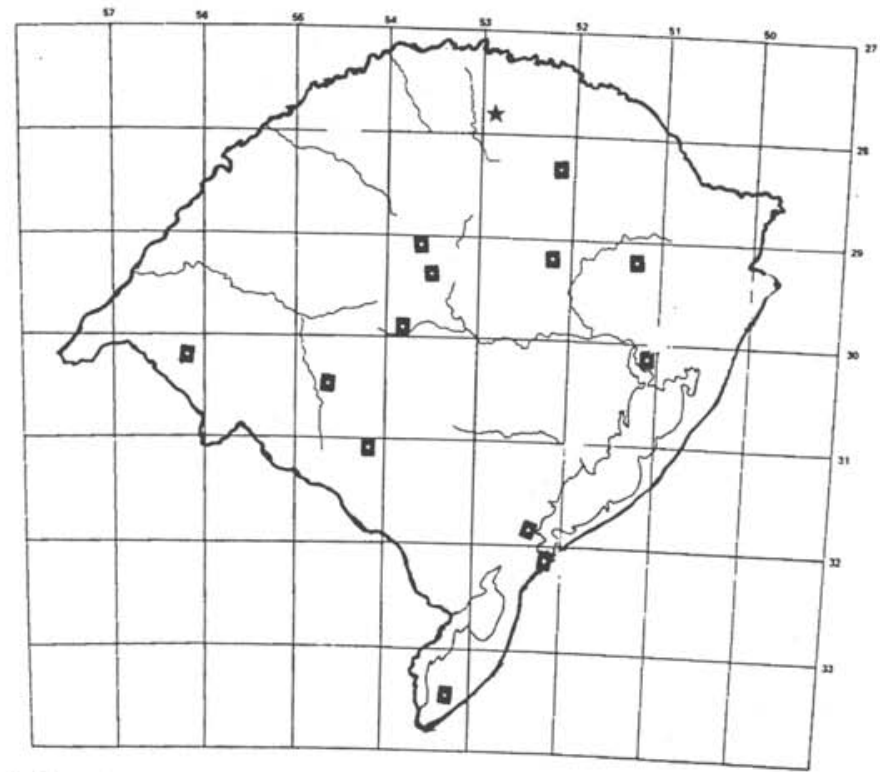

Figura 9. Distribuição de C. eragrostis ( ) e C. friburgensis ( ) no Rio Grande do Sul. 
apresenta uma grande variabilidade com relação à inflorescência, desde antelas laxas até inflorescências monocéfalas globosas. Entre estes dois extremos de variação existem exemplares que apresentam antelas pouco a muito congestas, que são em bem menor número do que os tipos extremos.

As populações com inflorescência monocéfala são tão homogêneas e o padrão da inflorescência tão bem definido que optou-se neste trabalho aceitá-las como $C$. haspan var. coarctatus .

As demais populações, com variação nas antelas ocorrendo em simpatria, foram aceitas como C. haspan var. haspan.

Quanto as diferenças ambientais C. haspan var. coarctatus ocorre apenas em terrenos alagadiços, especialmente em regiões litorâneas, enquanto $C$. haspan var. haspan ocorrem desde terrenos alagadiços a secos em todo o Estado.

\section{Material examinado}

BRASIL - RIO GRANDE DO SUL: Alegrete, para Uruguaiana, BR-290, 7 jan. 1991, Longhi-Wagner, A.C. Araujo et alii 2410 (ICN); Boçoroca, 14 dez. 1990, LonghiWagner \& A.C. Araujo et alii 2345 (ICN); Bom Jesus, Serra da Rocinha, 18 jan. 1950, Rambo 45371 (PACA), 14 dez. 1990, Longhi-Wagner, A.C. Araujo et alii 2275 (ICN); Canela, Sítio Garcés, 9 dez. 1990, L. Garcés s.n. (ICN 89357); Capão da Canoa, 11 jan. 1985, A. Pilz 733 (ICN), margem oriental da Lagoa dos Quadros, 10 mar. s. ano, M.L. Abruzzi 1082 (HAS); Caxias do Sul, 13 jan. 1954,Bertels 462 (PEL), Vila Oliva, 28 jan. 1946, Rambo 30746 (PACA); Jaguari, 8 jan. 1991, Longhi-Wagner, A.C. Araujo et alii 2431 (ICN); Pantano Grande, 6 jan. 1991, Longhi-Wagner, A.C. Araujo et alii 2359, 2360 (ICN); Passo Fundo, 9 jan. 1981, B. Severo et alii s.n. (RSPF 0912); Pelotas, 12 jan. 1951, Bertels 462 (PACA, UPCB), I.A.S., 4 dez. 1957, J.C. Sacco 803 (PEL, PACA, R); Porto Alegre, Morro da Glória, 5 fev. 1933, Rambo 697 (MVFA, PACA); Tenente Portela, Parque Estadual do Turvo, s.d., P. Brack s.n. (ICN 89180), 1586 (ICN), abr. 1983, M. Sobral 1912 (ICN); Tramandaí, 15 nov. 1990, Longhi-Wagner \& A.C. Araujo 2073, 2079, 2083, 2084, 2087, 2088, 2089 (ICN).

\section{Cyperus haspan var. coarctatus Nees (Figuras $7 \mathrm{~A}_{1}, 11$ )}

C. haspan var. coarctatus Nees, in Martius, Fl. Bras. 2 (1): 25. 1842. Tipo: Brasil, Bahia (não localizado).

C. haspan ssp. juncoides var. coarctatus (Nees) Kük., Pflanzenreich 4 (20): 248. 1936.

Perene, (15) 20-30 (89) cm de altura, densamente cespitosa, com rizomas muito curtos. Colmos (1) 1,5-2 (3) mm de largura, flácidos, triangulares de faces côncavas, lisos. Folhas com lâminas geralmente ausentes, poucas vezes desenvolvidas; bainhas (3) 7-10 (16) cm de comprimento, violáceas, às vezes castanho-claras, tênues no ápice da margem interna; lâminas 10-25 (30) mm de comprimento, (1,4) 2-4 mm de largura, lanceoladas, coriáceas, lisas nas margens.

Inflorescência monocéfala, globosa, 1-2,5 cm de comprimento, (1) 1,5-3 cm de 
largura, muito raramente com um raio isolado ou subcapituliforme. Brácteas involucrais 2, a inferior (1) 3-6 (11) cm de comprimento, (1,2) 2-4 mm de largura, raramente escabras nas margens e nervura central, superfície lisa. Prófilo tubular ausente. Prófilo espicular $(0,8)$ 1-1,3 mm de comprimento, 0,4-0,6 (0,9) mm de largura, ápice subagudo a truncado. Espiguetas 3,5-8 $\mathrm{mm}$ de comprimento, 1-3 mm de largura, lanceoladas a linear-lanceoladas, 5-20-floras; glumas 1-2 mm de comprimento, 0,5-0,8 mm de largura, ovado-elípticas, mucronadas, laxa a fortemente imbricadas, avermelhadas, às vezes amareladas, brilhantes, carena trinervada, esverdeada e lisa. Estames 3, conectivo rostrado com ápice estrelado; freqüentemente os filetes continuam aderidos ao fruto maduro. Aquênios 0,4-0,6 mm de comprimento, 0,3-0,4 mm de largura, ovados, trígonos, pálidos, superfície pontuada e brilhante, às vezes com uma cicatriz do estilete no ápice, estípete ausente.

Habitat: ocorre geralmente em banhados e campos alagados, especialmente em solos arenosos.

Distribuição geográfica:Brasil, Argentina e Uruguai. Foi citada também para os Estados Unidos (Kükenthal, 1936).

Fenologia: floresce e frutifica entre novembro e abril.

\section{Material examinado}

BRASIL - RIO GRANDE DO SUL: Santa Maria, Estação Experimental de Silvicultura, 10 mar. 1953, O. Camargo 27 (MVFA); Tramandaí, abr. 1953, J. Vidal 176, 184 (R), 25 mar. 1990, Longhi-Wagner \& A.C. Araujo 2009 (ICN), 15 nov. 1990, LonghiWagner \& A.C. Araujo 2076, 2080, 2085, 2086, 2090 (ICN).

\section{Cyperus incomtus Kunth (Figuras 10, 12)}

C. incomtus Kunth, Enum. Pl. 2: 39. 1837. Tipo: Brasil (Foto do holótipo: US!, ICN!)

Perene, (20) 30-60 cm de altura, densamente cespitosa, com rizomas muito curtos. Colmos 0,6-1,1 $(1,4) \mathrm{mm}$ de largura, trígonos, lisos, base raramente bulbosa. Folhas (2) 3-5 por colmo; bainhas (2) $3-5 \mathrm{~cm}$ de comprimento, violáceas, tênues no ápice da margem interna; lâminas (8) 20-40 (50) cm de comprimento, (1,2) 2-3 mm de largura, linear-lanceoladas, coriáceas, involutas, reticuladas, muitas vezes brilhantes, escabras nas margens.

Inflorescência monocéfala, capituliforme, $1-2,5 \mathrm{~cm}$ de comprimento, $(1,0)$ 1,5-3 $\mathrm{cm}$ de largura. Brácteas involucrais (2) 3-5, a inferior (6) $10-25 \mathrm{~cm}$ de comprimento, $(0,6)$ 1,5-2,5 mm de largura, revestimento semelhante às lâminas foliares, superfície reticulada. Prófilo tubular ausente. Prófilo espicular 1-1,5 mm de comprimento, 0,8-1 $(1,2) \mathrm{mm}$ de largura, ápice arredondado a subagudo. Espiguetas (5) 7-15 mm de comprimento, 2-3 mm de largura, oblongas, 10-30-floras; glumas 1,5-2,5 mm de comprimento, 1,2-1,6 mm de largura, largamente ovado-naviculares, mucronadas, fortemente imbricadas, esverdeadas, com pontuações marrons, finamente reticuladas, brilhantes, carena 5-nervada, esverdeada e lisa. Estame 1, conectivo não rostrado. Aquênios 1,2-1,5 (1,7) mm de comprimento, 0,6-0,9 (1) mm de largura, ovados, 
trígonos, castanhos a negros quando maduros, superfície pontuada, brilhante, às vezes recoberta por uma fina película hialina, ápice simetricamente apiculado, estípete raramente presente e pouco desenvolvido.

Habitat: ocorre comumente em locais sombreados de capões ou matinhas ciliares, e em campos secos ou úmidos. Também foi observada, com menor expressão, em locais alterados como lavouras abandonadas, beira de estradas, jardins e gramados.

Distribuição geográfica: Brasil, Argentina e Uruguai. Outros autores citaram sua ocorrência para o Paraguai (Osten, 1932; Kükenthal, 1936) e Peru (Kükenthal, 1936). Fenologia: floresce e frutifica principalmente de outubro a março. Eventualmente o florescimento pode se dar em setembro. Há registros de coleta para os meses de junho a agosto, mas o material coletado neste período apresenta inflorescências em estágio muito avançado de maturação, remanecentes do período anterior de florescimento.

\section{Material examinado}

BRASIL - RIO GRANDE DO SUL: Agudo, Cerro Agudo, set. 1985, M. Sobral et alii 4347 (ICN, MBM); Capão da Canoa, Praia de Xangrila, s.d., M.L. Abruzzi 782 (HAS); Caxias do Sul, nov. 1977, T. Buselato 111 (HAS); Cerro Largo, 16 dez. 1990, Longhi-Wagner, A.C. Araujo et alii 2328, 2329 (ICN), 20 nov. 1952, Rambo 53135 (PACA); Dom Pedrito, próximo rio Piraí, 7 dez. 1991, Longhi-Wagner, A.C. Araujo et alii 2514 (ICN); Ijuí, Pestana, 11 out. 1953, Pivetta 738 (PACA), Posto Agropecuário, 10 dez. 1974, L. Arzivenco s.n. (ICN 42950); Pelotas, 24 ago. 1956, Bertels 463 (PACA); Porto Alegre, 9 nov. 1990, Longhi- Wagner 2033 (ICN), 6 dez. 1990, A.C. Araujo s.n. (ICN 89378); Tenente Portela, 23 jul. 1969, B. Irgang et alii s.n.(ICN 5935), Parque Estadual do Turvo, s.d., P. Brack s.n. (ICN 89190), abr. 1983, M. Sobral 1919, 2015 (ICN); Vacaria, 3 dez. 1956, L.B. Smith \& Klein 8170 (US, R).

9. Cyperus luzulae (L.) Retz. var. Luzulae (Figuras 13 A,C-G, 17)

C. luzulae (L.) Retz., Observ. 4: 11. 1786.

Scirpus luzulae L., Sp. Pl. 2: 75. 1762. Tipo: India oeste ou Suriname. Linnaean Herbarium no. 71-45 (holótipo LINN, fotocópia do tipo ICN !).

C. luzulae var. minor Boeckeler, Linnaea 35: 561. 1868. Tipo: Suriname, Hostmann s.n. (holótipo: B!).

C. pseudosurinamensis Boeckeler, Allg. Bot. Zeitschr. Syst. 1: 201. 1895. Tipo: Martinique, Hahn s.n. (holótipo: B !).

Perene, 30-80 (100) $\mathrm{cm}$ de altura, densamente cespitosa, com rizomas muito curtos. Colmos $(1,5)$ 2-3,5 $\mathrm{mm}$ de largura, trígonos, lisos, raramente com ângulos escabros. Folhas (4) 5-7 (10) por colmo; bainhas 3-8 (10) cm de comprimento, violáceas bem junto ao rizoma, no restante amareladas, tênues no ápice da margem interna; lâminas (15) 30-60 cm de comprimento, 3-7,5 mm de largura, lanceoladas, coriáceas, reticuladas e brilhantes, escabras nas margens e mais densamente na nervura central.

Inflorescência em antela simples, $(1,5) 2,5-7(10) \mathrm{cm}$ de comprimento, $2-10 \mathrm{~cm}$ 
de largura, com 4-8 (10) raios primários de 1-4 (8) cm de comprimento, espiguetas reunidas em glomérulos no ápice, raios secundários raramente presentes. Brácteas involucrais (3) 5-8, a inferior (12) $25-60 \mathrm{~cm}$ de comprimento, 3-7 $\mathrm{mm}$ de largura, escabra na nervura central, margens lisas ou escabras, superfície reticulada e brilhante. Prófilo tubular 5-7 (9) mm de comprimento, membranáceo, amarelado, raramente avermelhado, ápice bidentado; prófilo espicular, 0,6-1 mm de comprimento, $(0,3)$ 0,4$0,8 \mathrm{~mm}$ de largura, ápice truncado, às vezes subagudo. Espiguetas $3-6(7,5) \mathrm{mm}$ de comprimento, (1,5) 2-2,5 mm de largura, ovadas, (7) 10-25-floras; glumas 1,5-2 mm de comprimento, 0,6-1 mm de largura, lanceoladas, ápice obtuso, bem imbricadas, com margens onduladas, amareladas, às vezes esverdeadas, superfície reticulada, carena trinervada, esverdeada, lisa. Estame 1, conectivo rostrado com o ápice agudo. Aquênios $(0,8)$ 1-1,3 mm de comprimento, 0,2-0,4 mm de largura, elípticos, trígonos, castanhos a negros quando maduros, superfície pontuada e brilhante, muitas vezes recoberta por uma película hialina reticulada, ápice simetricamente apiculado e negro, estípete ausente.

Habitat: ocorre em ambientes variados como campos úmidos e secos, baixadas úmidas, pântanos, banhados, beira de lagoa e interior de matas, sendo entretanto mais comum em locais alterados, como jardins abandonados e beira de estradas.

Distribuição geográfica: Brasil, Argentina, Costa Rica, Equador, Guiana Francesa, Panamá, Peru, Uruguai e Venezuela. Foi também citada para a Colômbia, Cuba, El Salvador, Estados Unidos, Guatemala, Honduras, Jamaica, México, Nicarágua, Paraguai, Suriname e Trinidad.

Fenologia: floresce e frutifica de setembro a abril. Em outras regiões do Brasil há registro de coletas para todos os meses do ano.

\section{Comentários}

Cyperus entrerianus e C. luzulae foram consideradas espécies diferentes por Osten (1932), Kükenthal (1936), Boldrini \& Cunha (1984) e Tucker (1985) com base no padrão da inflorescência. Barros (1938, apud Tucker 1985) entretanto, considerou C. entrerianus como variedade de C. luzulae, enquanto Denton (1978) a incluiu na sinonímia desta última espécie sem adotar variedades.

O caráter morfológico principal para estes dois diferentes tratamentos é o tipo de inflorescência, embora alguns poucos tipos intermediários tenham sido observados.

Quanto aos demais caracteres da morfologia externa, analisados neste trabalho, não há uma clara descontinuidade morfológica, com superposição dos dados quantitativos e combinação aleatória dos caracteres.

No Rio Grande do Sul, populações com os dois tipos de inflorescência ocorrem em simpatria, em praticamente todas as regiões do Estado, sempre associadas a ambientes alterados.

Devido ao exposto acima é adotado a separação de $C$. luzulae em duas variedades, embora reconhecendo a necessidade de estudo biossistemático em uma área geográfica mais abrangente para esclarecer definitivamente a circunscrição destes dois taxa. 


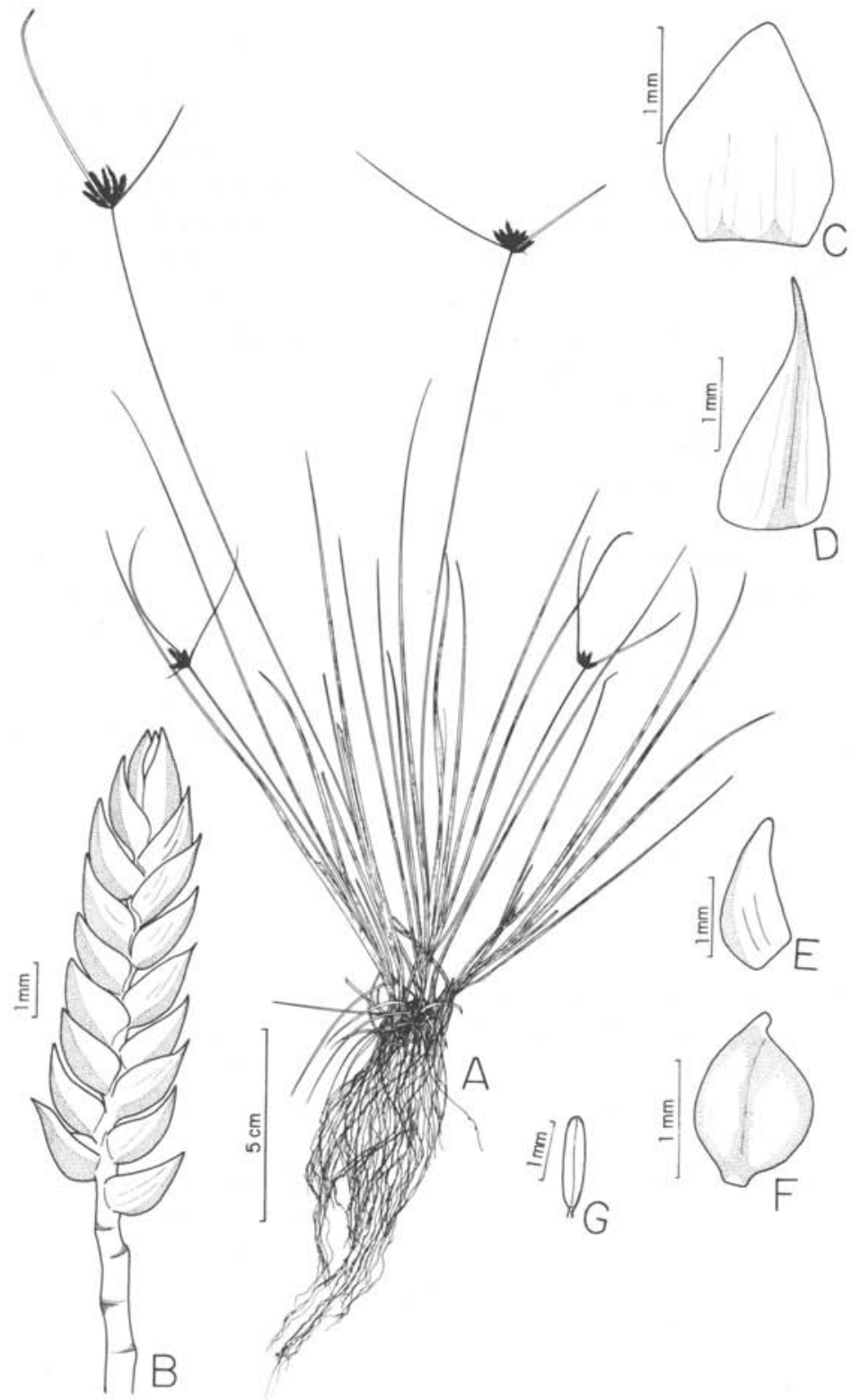

Figura 10. Cyperus incomtus (Longhi-Wagner 2033 - ICN) A: hábito; B: espigueta prófilo espicular e gluma bracteóide retirados, glumas férteis basais caídas; C: prófilo espicular; D: gluma bracteóide; E: gluma fértil; F: fruto; G: estame. 


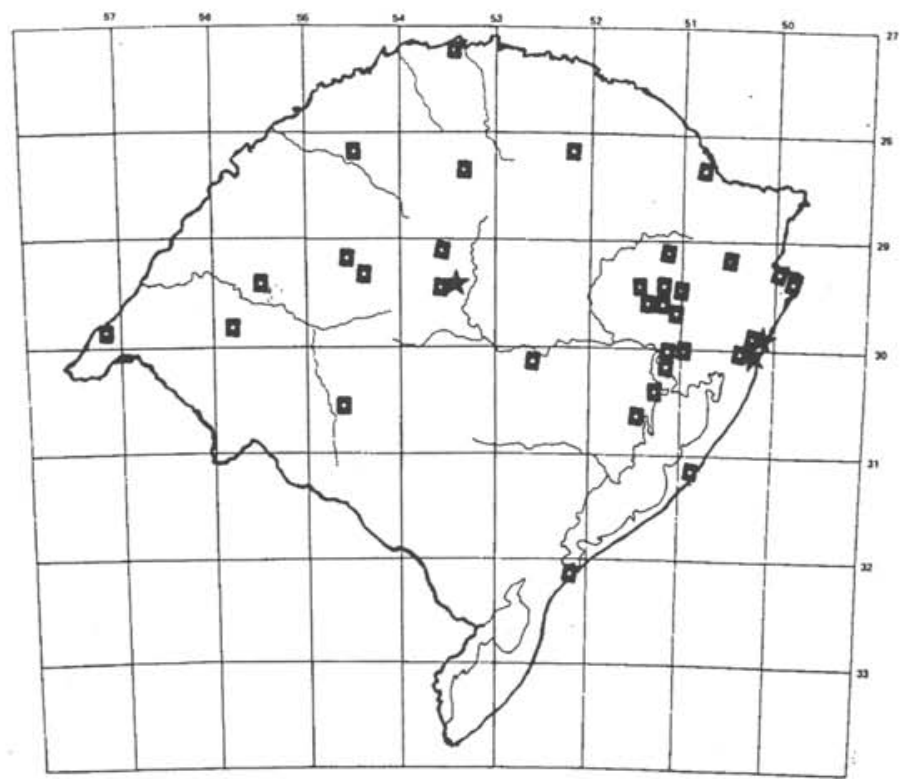

Figura 11. Distribuição das variedades de C. haspan no Rio Grande do Sul.

C haspan var. haspan ( $\downarrow$ )

C. haspan var. coarctatus ( )

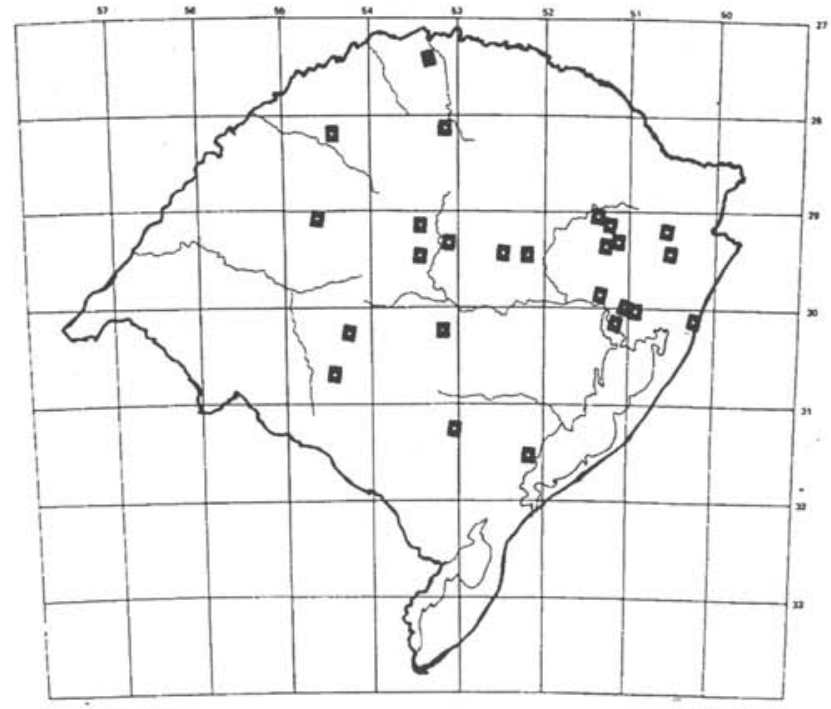

Figura 12. Distribuição de $C$. incomtus no Rio Grande do Sul. 


\section{Material examinado}

BRASIL - RIO GRANDE DO SUL: Alegrete, 7 jan. 1991, Longhi-Wagner, A.C. Araujo et alii 2417 (ICN); Caçapava do Sul, 6 jan. 1991, Longhi-Wagner, A.C. Araujo et alii 2372 (ICN); Farroupilha, sd. O. Camargo 2568 (PACA); Lageado, 11 dez. 1990, L. Garcés s.n. (ICN 89343); Jaguari, 8 jan. 1991, Longhi-Wagner et alii 2432 (ICN ); Marcelino Ramos, s.d., Pott 19 (BLA); Panambi, 15 dez. 1990, LonghiWagner, A.C. Araujo et alii 2311 (ICN); Pelotas, 7 dez. 1990, Longhi- Wagner, A.C Araujo et alii 2159 (ICN), para Bagé, 7 dez. 1990,Longhi-Wagner, A.C. Araujo et alii 2159 (ICN); Porto Alegre, 29 abr. 1977, Longhi-Wagner et alii s.n. (ICN 35255), Parque da Redenção, 6 dez. 1990, A.C. Araujo s.n. (ICN 89376, 89377), Praia de Belas, 15 mar. 1967, A.G. Ferreira 121 (ICN); Rio Grande, Estação Ecológica do Taim, 3 nov. 1985, Jarenkow et alii 245 (PEL); São Francisco de Paula, Fazenda Englert, 16 jan. 1938, L. Maurman 2996 (PACA).

10. Cyperus luzulae var. entrerianus (Boeckeler) Barros (Figuras $13 \mathrm{~B}, 17$ )

C. luzulae var. entrerianus (Boeckeler) Barros, Anales Mus. Argent. Sci. Nat. 39: 309. 1938.

C. entrerianus Boeckeler, Flora 61: 139. 1878. Tipo: Argentina. Concepción del Uruguay, Abr.1876, Lorentz s.n. (holótipo B !).

C. tucumanensis Boeckeler, Bot. Jahrb. Syst. 7: 274. 1886. Tipo: Argentina. Tucumán, 29 dez. 1872, Lorentz \& Hieronymus 1086 (holótipo: B !).

Perene, $50-110 \mathrm{~cm}$ de altura, densamente cespitosa, com rizomas muito curtos. Colmos 2-4 mm de largura, trígonos, lisos, raramente escabros nos ângulos, próximo ao ápice. Folhas (3) 5-8 (11) por colmo; bainhas (3) $5-9 \mathrm{~cm}$ de comprimento, violáceas, tênues no ápice da margem interna; lâminas (20) $40-80 \mathrm{~cm}$ de comprimento, 5-10 mm de largura, lanceoladas, coriáceas, reticuladas e brilhantes, escabras nas margens e nervura central.

Inflorescência em antela composta, contraída, (5) 7-12 cm de comprimento, (5) 7 $15 \mathrm{~cm}$ de largura, com 7-10 (12) raios primários de $5-9 \mathrm{~cm}$ de comprimento, raios secundários 0,5-2 cm de comprimento, espiguetas reunidas em glomérulos densos no ápice. Brácteas involucrais 5-10, a inferior (20) 30-50 (60) cm de comprimento, 4,5-7,5 $\mathrm{mm}$ de largura, escabras nas margens e nervura central, superfície reticulada, muito semelhantes às lâminas foliares. Prófilo tubular (7) 8,5-12 mm de comprimento, membranáceo, amarelado, ápice agudo, avermelhado; prófilo espicular $(0,6) 0,7-1(1,2) \mathrm{mm}$ de comprimento, 0,4-0,6 mm de largura, ápice truncado, às vezes subagudo. Espiguetas 2-6 mm de comprimento, 1,5-2,5 mm de largura, ovadas, 5-12 (20)-floras; glumas 1,2$2 \mathrm{~mm}$ de comprimento, 0,6-0,9 mm de largura, lanceoladas, ápice arredondado, bem imbricadas, amareladas, com margens onduladas, superfície reticulada e brilhante, carena trinervada, esverdeada ou alaranjada, geralmente lisa, às vezes escabra no ápice. Estame 1, conectivo rostrado com o ápice agudo. Aquênios 0,8-1,1 mm de comprimento, 0,3-0,4 mm de largura, elípticos, trígonos, castanho-escuros a negros quando maduros, 
superfície reticulada e brilhante, frequentemente recoberta por uma película hialina e reticulada, ápice assimetricamente apiculado, estípete ausente.

Habitat: campos úmidos ou secos, baixadas úmidas, freqüentemente em solos arenosos. É comum também em locais alterados como aterros, beira de estradas e como invasora de gramados e jardins.

Distribuição geográfica: Brasil, Argentina, Paraguai, Uruguai e Venezuela. Foi também citada para a Bolívia, Colômbia, Costa Rica, Cuba, Estados Unidos, Jamaica e Nicarágua.

Fenologia: floresce e frutifica entre os meses de novembro e março, podendo eventualmente ser encontrada fértil no mês de abril. Apenas uma coleta, fora do Estado do Rio Grande do Sul, é registrada para o mês de julho.

\section{Material examinado}

BRASIL - RIO GRANDE DO SUL, Bagé, 2 abr. 1985,J. Mattos et alii 29015 (HAS); Cambará do Sul, Itaimbezinho, nov. 1977, S.C. Boechat S.n. (ICN 43322); Cerro Largo, 16 fev. 1990, Longhi-Wagner, A.C. Araujo et alii 2327 (ICN); Cristal, BR 116, 7 dez. 1990, Longhi- Wagner, A.C. Araujo et alii 2138 (ICN); Gravataí, 14 jan. 1991, A.C. Araujo I (ICN); Montenegro, s.d., Pott (BLA 12104); Pantano Grande, 6 jan. 1991, Longhi-Wagner, A.C. Araujo et alii 2361 (ICN); Parobé, 14 jan. 1991, A.C. Araujo 27 (ICN); Porto Alegre, Colégio Anchieta, 26 nov. 1990, Longhi-Wagner 2132, 2133 (ICN), Parque da Redenção, fev. 1991, A.C. Araujo 28 (ICN); Tramandaí, 23 mar. 1990, Longhi-Wagner \& A.C. Araujo s.n. (ICN 90905), 15 nov. 1990, LonghiWagner \& A.C. Araujo 2062 (ICN); Tupanciretã, 4 fev. 1969, Pott 348 (BLA), s.d., Pott \& Valls s.n. (BLA 13374).

11. Cyperus reflexus Vahl var. reflexus (Figuras $14 \mathrm{~A}-\mathrm{G}, 18$ ) C. reflexus Vahl, Enum. 2: 299. 1806. Tipo: USA, Texas, Drumond I (isótipo: P!).

Perene, (14) 60-100 cm de altura, com rizomas curtos ligando colmos isolados. Colmos 1-3 mm de largura, cilíndricos ou obscuramente trígonos na base e claramente trígonos no ápice, lisos, com base bulbosa. Folhas (2) 3-6 (10) por colmo; bainhas (1) 3,5-7 (18) cm de comprimento, avermelhadas, amareladas quando secas, tênues no ápice da margem interna; lâminas (9) 14-24 (45) cm de comprimento, 1,5-3 (5,5) mm de largura, lineares, coriáceas, reticuladas, margens lisas ou raramente escabras.

Inflorescência monocéfala, globosa, 1,5-3 (4) cm de comprimento, 1,5-3 (5) cm de largura, muito raramente levando 1-2 capítulos curtos. Brácteas involucrais (2) 34, a inferior (5) 7- 10 (17) $\mathrm{cm}$ de comprimento, (1) 2-3 (4) $\mathrm{mm}$ de largura, nervura central escabra,margens e superfície lisa. Prófilo tubular ausente. Prófilo espicular 0,8-1,1 $\mathrm{mm}$ de comprimento, 0,6-0,8 $\mathrm{mm}$ de largura, ápice arredondado. Espiguetas (5) 7-10 (15) $\mathrm{mm}$ de comprimento, 1-2,5 mm de largura, lanceoladas, (10) 20-30 (40)floras; glumas 1,5-2 mm de comprimento, 1-1,5 (2) mm de largura, lanceoladas, naviculares, ápice subagudo a agudo, bem imbricadas, avermelhadas a violáceas, reticuladas, carena trinervada, geralmente esverdeada, às vezes avermelhada, lisa. 


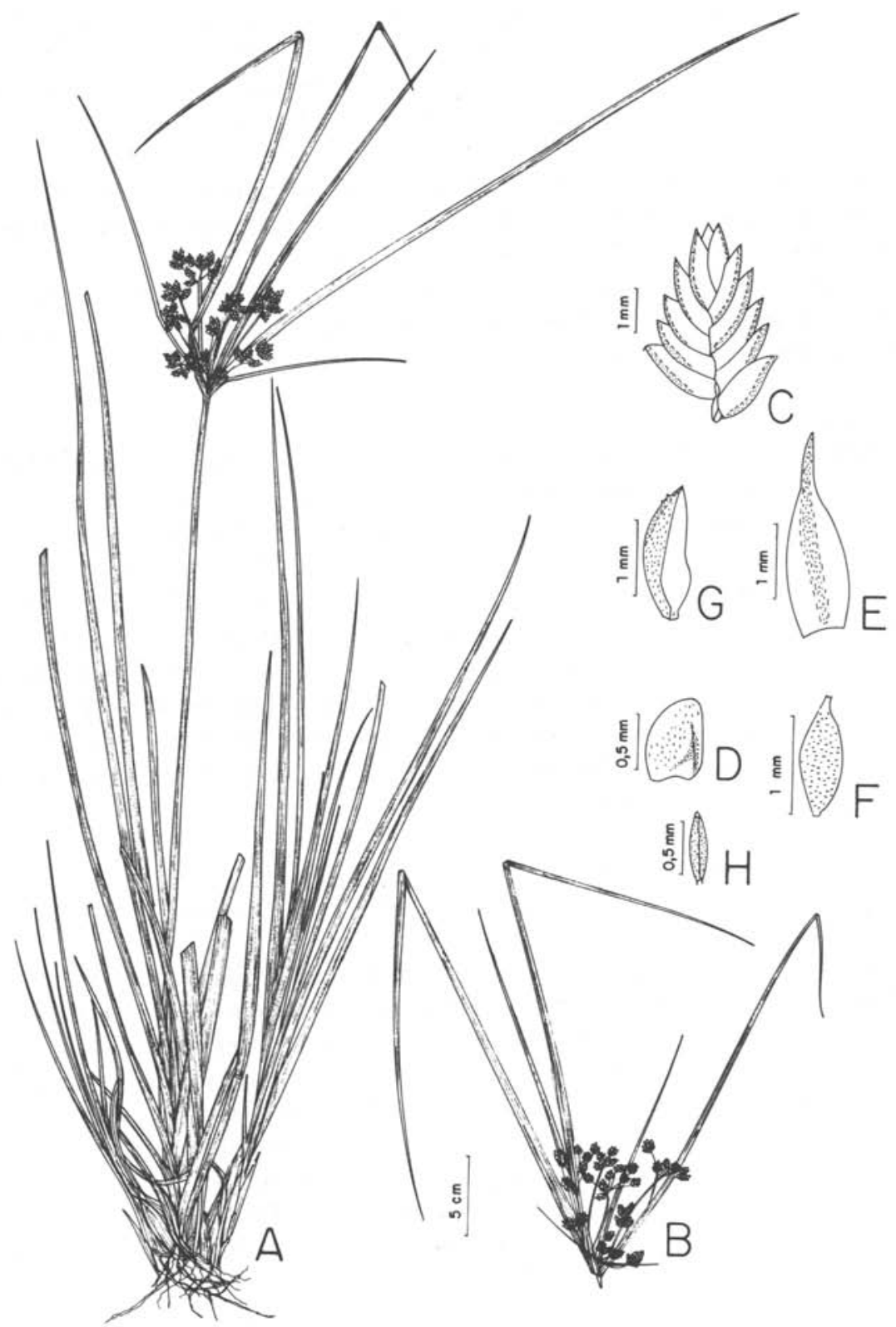

Figura 13. Cyperus luzulae var. luzulae (Longhi-Wagner \& A. C. Araújo 2432 - ICN)

A: hábito; C: espigueta, prófilo espicular e gluma bracteóide retirados; D: prófilo espicular; E: gluma bracteóide; G: gluma fértil; $\mathrm{F}$ : fruto; $\mathrm{H}$ : antera.

B: inflorescência de Cyperus luzulae var. entrerianus (Longhi-Wagner \& A. C. Araújo 2138 - ICN). 


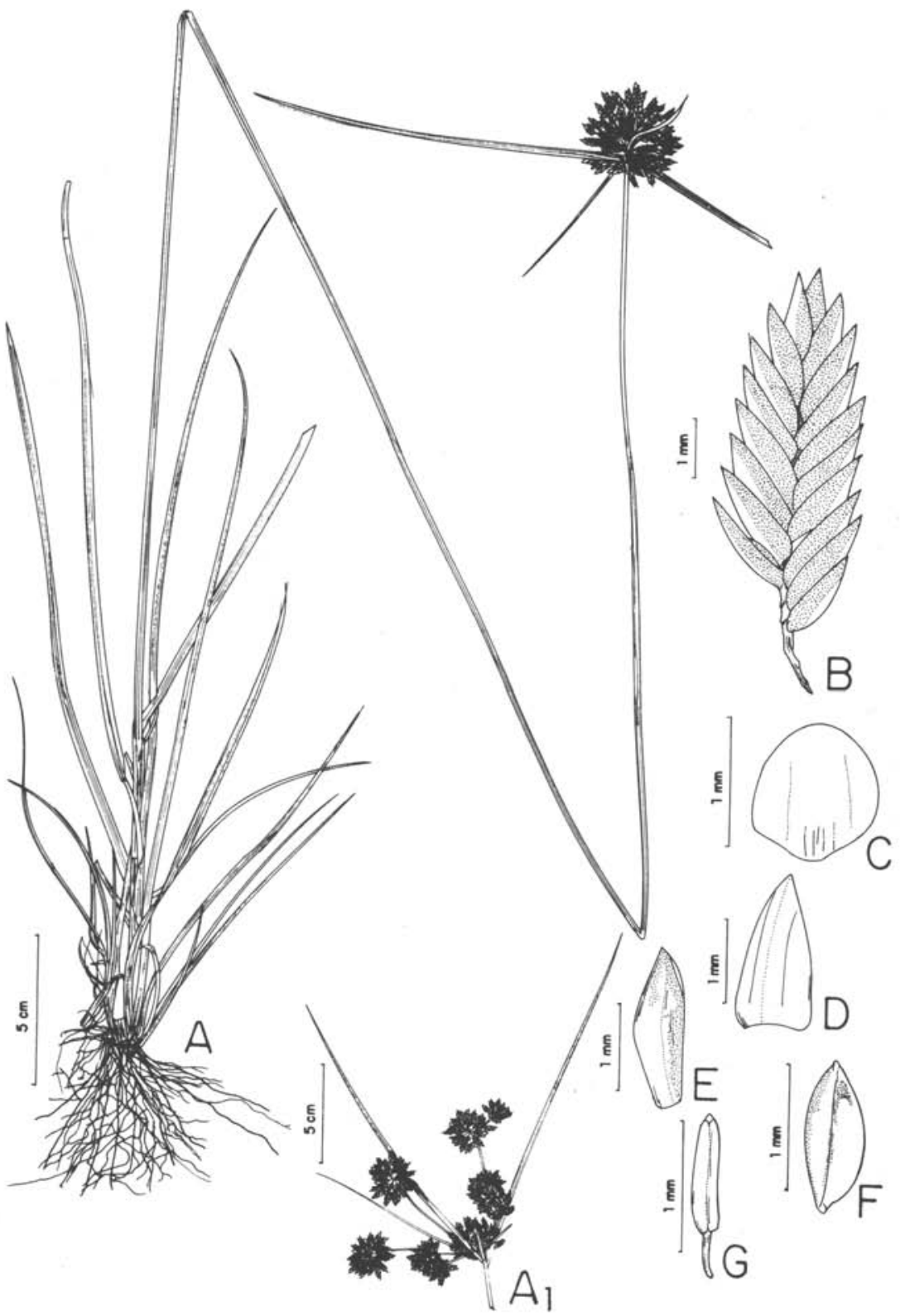

Figura 14. Cyperus reflexus var. reflexus (Longhi-Wagner, A. C. Araújo et al. 2380 - ICN)

A: hábito; B: espigueta, prófilo espicular e gluma bracteóide retirados, glumas férteis basais caídas; C: prófilo espicular; D: gluma bracteóide; E: gluma fértil; F: fruto; G: estame.

AI: inflorescência de Cyperus reflexus var. fraternus (Longhi-Wagner \& A. C. Araújo 2237 - ICN). 
Estame 1, conectivo rostrado com o ápice agudo. Aquênios $(0,8) 1-1,2(1,5) \mathrm{mm}$ de comprimento, $(0,3)$ 0,4-0,6 mm de largura, elípticos, triangulares de faces retas, castanhos, negros ou às vezes acinzentados quando maduros, superfície reticulada, geralmente recoberta por uma película hialina, ápice simetricamente apiculado, estípete ausente.

Habitat: ocorre em campos secos e úmidos, aterro, dunas úmidas, turfeiras, barranco pedregoso e beira da estrada.

Distribuição geográfica: Brasil, Argentina, México, Paraguai e Uruguai. Há citações para a Bolívia, Chile, Estados Unidos e Peru.

Fenologia: floresce e frutifica de outubro até março, poucas vezes florescendo até abril. Exemplares coletados em data posterior apresentam estruturas férteis danificadas. Nas demais regiões do Brasil o período de florescimento é mais longo, entre setembro e abril.

\section{Comentários}

Cyperus fraternus Kunth foi aceita como variedade de $C$. reflexus com base no distinto pladrão de infloresência associado a ambientes preferenciais diferentes de cada taxon. Tipo semelhante de variação de inflorescência observado para C. haspan, foi observado em C. reflexus. Deste modo, em C. reflexus var. reflexus a inflorescência é monocéfala globosa, e em C. reflexus var.fraternus a inflorescência é do tipo antela simples. Além disso, foi observado alguns poucos exemplares em que a inflorescência monocéfala apresentava um a dois ramos laterais.

Com relação ao ambiente observou-se que as populações desta última variedade desenvolvem-se preferencialmente em ambientes bastante úmidos, enquanto as populações da primeira suportam ambientes secos e até rupestres.

Em nossa opinião estes dois fatores são suficientes para distinguir os dois taxa, porém não o bastante para considerá-los espécies diferentes, haja visto que não apresentam descontinuidade nos demais caracteres morfológicos, vegetativos e reprodutivos. Os demais taxa relacionados com estas variedades são postos na sinonímia das mesmas.

\section{Material examinado}

BRASIL - RIO GRANDE DO SUL: Alegrete, 7 jan. 1991, Longhi-Wagner, A.C. Araujo et alii 2420 (ICN), Tigre, Guarita, J.Mattos 6276 (HAS), $8 \mathrm{Km}$ após hipódromo de Capão do Tigre, 14 dez. 1990, Longhi-Wagner, A.C. Araujo et alii 2283 (ICN); Bom Jesus, 15 jan. 1942, Rambo 8885 (PACA); Caçapava do Sul, 7 dez. 1990, Longhi-Wagner, A.C. Araujo et alii 2181 (ICN); Canela, 3 dez. 1981, J. Mattos \& N. Mattos 30591 (HAS); Osório, 4 jan. 1950, Rambo 45221 (PACA); Passo Fundo, 20 jan. 1950, s. col. (PEL 2177), TV Umbú, ano 1989, R. Zauda \& C. Biolo s.n. (RSPF 4258); Pelotas, I.A.S., 14 nov. 1955, J.C. Sacco 412 (PKDC, R), 9 jan. 1958. J.C. Sacco 883 (PEL), 7 dez. 1990, Longhi-Wagner, A.C. Araujo et alii 2158 (ICN); Porto Alegre, Morro Santana, 9 nov. 1990, Longhi-Wagner 2030 (ICN), dez. 1990, I. 
Boldrini s.n. (ICN 8939); Rio Grande, 7 nov. 1901, Malme 86 (R); Santiago, 7 jan. 1991, Longhi-Wagner, A.C. Araujo et alii 2397 (ICN); São Francisco de Paula, A.C. Araujo 17 (ICN); São Vicente do Sul, 8 jan. 1991, Longhi-Wagner, A.C. Araujo et alii 2433 (ICN); Vacaria, 15 dez. 1990, Longhi-Wagner, A.C. Araujo et alii 2299 (ICN).

12. Cyperus reflexus var. fraternus (Kunth) Kuntze (Figuras $14 \mathrm{~A}_{1}, 18$ )

C. reflexus var. fraternus (Kunth) Kuntze, Rev. Gen. Pl. 3 (2): 334. 1898.

C. fraternus Kunth, Rev. Gen. Pl. 2: 42. 1837. Tipo: Brasil, Sello s.n. (holótipo: B !). C. rufensis Torrey \& Hooker, Ann. Lyceum Nat. Hist. New York 3: 436. 1836. Tipo: USA, Texas, Rio Brazos, Drummond s.n. (lectótipo: NY !).

C. surinamensis var. strictus Kuk., Pflanzenreich 4 (20): 175. 1936. Tipo:Paraguai, dez. 1901, Hassler 8195 (holótipo: B!; isotipo: NY-2).

Perene, 60-80 (145) cm de altura, com rizomas curtos ligando colmos isolados. Colmos (1) 2-3 (5) mm de largura, cilíndricos ou obscuramente trígonos na base e claramente trígonos no ápice, diminuindo o diâmetro em direção ao ápice, lisos, com base bulbosa. Folhas (1) 3-6 por colmo; bainhas (3) 4-6 (10) cm de comprimento, rosadas a violáceas, tênues no ápice da margem interna; lâminas (15) 25-40 (55)cm de comprimento, (1,5) 3-4 (6) mm de largura, linear-lanceoladas, coriáceas, reticuladas, margens lisas ou raramente escabras.

Inflorescência em antela simples, contraída, $(1,5) 3-5$ (12) cm de comprimento, $(1,5)$ 3-5 (12) $\mathrm{cm}$ de largura, com 2-4 (8) raios primários de $3-4(12) \mathrm{cm}$ de comprimento, espiguetas reunidas em glomérulos no ápice, raios secundários raramente presentes. Brácteas involucrais (3) 4-6, a inferior (8) $13-20 \mathrm{~cm}$ de comprimento, 1,5-3 (4) mm de largura, revestimento semelhante à lâmina foliar, superfície reticulada. Prófilo tubular (3) $5-7 \mathrm{~cm}$ de comprimento, alaranjado, ápice subagudo; prófilo espicular $(0,6)$ 0,9-1,2 $\mathrm{mm}$ de comprimento, 0,4-0,7 mm de largura, ápice arredondado a subagudo. Espiguetas (3) 4-6 (8) $\mathrm{mm}$ de comprimento, 1,5-2,5 $\mathrm{mm}$ de largura, lanceoladas, raramente ovadas, (5) 10-20 (30)-floras; glumas 1,5-2,5 mm de comprimento, 0,6-1 mm de largura, lanceoladas, naviculares, ápice subagudo, bem imbricadas, avermelhadas ou alaranjadas, reticuladas, carena trinervada, geralmente esverdeada, alaranjada quando os lados da gluma são bem avermelhados, lisa. Estame 1, conectivo rostrado com o ápice agudo. Aquênios 0,9-1,1 $(1,2) \mathrm{mm}$ de comprimento, 0,3-0,5 mm de largura, elípticos, trígonos, às vezes triangulares de faces retas, castanho-escuros a negros quando maduros, superfície reticulada ou com pontuações brilhantes, geralmente recoberta por uma película hialina, ápice simetricamente apiculado, estípete ausente.

Habitat: ocorre em campos secos e úmidos, banhados e baixadas úmidas, beira de mata e campos periodicamente inundáveis. Está mais comumente associada a ambientes úmidos e alagados do que $C$. reflexus var. reflexus.

Distribuição geográfica: Brasil e Uruguai. Também foi citada para a Argentina, Estados Unidos e México.

Fenologia: floresce e frutifica de outubro a março. Eventualmente é possível encon- 
trar em junho indivíduos no início do florescimento. Esta variedade, como é comum para os demais taxa estudados, tem um período mais longo de florescimento em outras regiões do Brasil.

\section{Material examinado}

BRASIL - RIO GRANDE DO SUL: Alegrete, 5 dez. 1978, Cristóbal \& Krapovickas 34158 (MBM); Bom Jesus, 14 dez. 1990, Longhi-Wagner, A.C. Araujo et alii 2269, 2279 (ICN); Canela, 16 jan. 1954, Bertels 1070 (PEL); Cerro Largo, 16 dez. 1990, Longhi- Wagner, A.C. Araujo et alii 2332 (ICN); Cruz Alta, dez. 1986, M. Sobral 5289 (ICN); Farroupilha, 18 nov. 1957, O. Camargo 2568a (PACA); Osório, Aguapé, set. 1985, M. Sobral \& R. Schmidt 4132 (MBM); Pantano Grande, 6 jan. 1991, Longhi-Wagner, A.C. Araujo et alii 2363 (ICN); Pelotas, 15 out. 1950, Bertels 450 [112] (UPCB); Porto Alegre, Morro Santana, 26 jun. 1979, J. Mariath 705 (HAS); Taquara, 14 jan. 1991, A.C. Araujo 9 (ICN).

13. Cyperus surinamensis Rottb. (Figuras 15, 19)

C. surinamensis Rottb., Descr. Ic. Rar. 35: 16. 1773. Tipo: Suriname.

C. denticulatus Schrader ex Schultes, in Roem. \& Schultes, Syst. Veg. Mantissa 2: 104. 1824. Tipo: Brasil, Prinz von Wied-Neuwied (isótipo: C!).

C. biponti Boeckeler, Flora 40: 33.1857. Tipo: Vera Cruz, Herb. Boeckeler (holótipo B!).

C. surinamensis var. lutescens Boeckeler, Linnaea 35: 555. 1868. Tipo: Lagoa Santa, nov., Warming s.n. (neótipo: C).

Perene, 10-25 (60) $\mathrm{cm}$ de altura, densamente cespitosa, com rizomas muito curtos. Colmos $(0,8) 1,1-1,4(2,2) \mathrm{mm}$ de largura, trígonos, raramente triangulares, escabros nos ângulos e nas faces, com base bulbosa. Folhas 1-3 (4) por colmo; bainhas (1) 1,5-2,5 $(3,5) \mathrm{cm}$ de comprimento, rosadas a violáceas, mais raramente amareladas, tênues no ápice da margem interna; lâminas (5) 9-20 (30) cm de comprimento, 1,5-3 mm de largura, lineares à linear-lanceoladas, coriáceas, reticuladas e brilhantes, margens lisas ou às vezes escabras nas folhas mais velhas.

Inflorescência em antela simples ou composta, pouco contraída, $(1,5) 3-6 \mathrm{~cm}$ de comprimento, 3-6 cm de largura, com (2) 4-5 (6) raios primários de (1) 3-5 cm de comprimento, raios secundários $0,5-1,5 \mathrm{~cm}$ de comprimento, levando no ápice espiguetas reunidas em glomérulos. Brácteas involucrais 2-4, a inferior (4) 5,5-8 (18) cm de comprimento, 1,4-1,8 $(2,8) \mathrm{mm}$ de largura, escabras na nervura central e mais raramente nas margens, superfície reticulada e brilhante. Prófilo tubular 2,3-3,4 mm de comprimento, rosado, ápice arredondado; prófilo espicular $(0,4)$ 0,6-0,9 mm de comprimento, 0,3 $\mathrm{mm}$ de largura, ápice subagudo. Espiguetas 3-9 (12) mm de comprimento, 1,2-1,4 (2) mm de largura, lanceoladas, (6) 14-30 (60)-floras; glumas 1$1,2(1,4) \mathrm{mm}$ de comprimento, 0,6-0,8 (1) $\mathrm{mm}$ de largura, lanceoladas, naviculares, ápice subagudo, fortemente imbricadas, amareladas ou esverdeadas, raramente esbranquiçadas, reticuladas e brilhantes, carena trinervada, esverdeada e lisa. Estame 1, 
conectivo rostrado com o ápice agudo. Aquênios 0,6-0,7 (1) mm de comprimento, $(0,2) 0,3 \mathrm{~mm}$ de largura, elípticos, trígonos, castanho-claros a avermelhados quando maduros, superfície rugosa, muito brilhante, ápice simetricamente apiculado, estípite ausente.

Habitat: ocorre em terrenos baldios, beira de estradas, aterros, geralmente associada a ambientes alterados, em solos arenosos, secos ou úmidos.

Distribuição geográfica: Brasil, Argentina, Equador, Guiana Francesa e Uruguai. Há citações para a Austrália, Bolívia, Colômbia, Costa Rica, Cuba, El Salvador, Estados Unidos, Guatemala, Guiana Inglesa, Haiti, Honduras, Jamaica, México, Nicarágua, Panamá, Paraguai, Peru, Porto Rico, Trinidad e Venezuela.

Fenologia: floresce e frutifica de novembro a março, raramente se estendendo até abril, quando apresenta restos de inflorescência. Em outros locais do Brasil há várias coletas registradas para abril e maio.

\section{Material examinado}

BRASIL - RIO GRANDE DO SUL: Imbé, 25 mar. 1990, Longhi-Wagner \& A.C. Araujo 2021 (ICN); Porto Alegre, Praia de Belas, 10 abr. 1967, A.G. Ferreira 164 (ICN); Rio Grande, Estação Ecológica do Taim, 23 fev. 1984, B.L.G. 19 (ICN); Tapes, Fazenda Capão da Moça, 23 mar. 1986, Nhuch s.n.(ICN 89020), Sudeste-S, 16 mar. 1986, Nhuch s.n. (ICN 89017, 89021, 89022).

14. Cyperus virens Michaux (Figuras 16, 19)

C. virens Michaux, Fl. Bor. Amer. 1: 38. 1803. Tipo: EUA, Carolina, 1786-96, Michaux s.n. (foto do isótipo: ICN!).

C. minarum Boeckeler, Beitr. Cyper. 2: 5. 1890. Tipo: Brasil. Minas Gerais, 1845, Widgren s.n. (isótipo C!).

C. montanus Boeckeler, Beitr. Cyper. 2: 4. 1890. Tipo: Argentina, Picada a'San Pedra, Cordilheira de Missiones, 29 out. 1886, Niederlein 2116 (holótipo: B).

C. virens var. montanus (Boeckeler) Denton, Contr. Univ. Mich. Herb. 11 (4): 265. 1978.

Perene, 40-85 (145) $\mathrm{cm}$ de altura, densamente cespitosa, com rizomas muito curtos. Colmos (1,4) 2,5-5 mm de largura, triangulares, escabros nos ângulos, principalmente na região apical ou, mais raramente, escabros em apenas um dos ângulos. Folhas (3) 4-6 por colmo; bainhas (4) 6-12 (38) cm de comprimento, violáceas a rosadas, às vezes amareladas, tênues no ápice da margem interna; lâminas 25-50 (80) cm ou mais de comprimento, (3) 5-7 (11) mm de largura, linear-lanceoladas, coriáceas, reticuladas, geralmente escabras nas margens, raramente apenas escabras na nervura central.

Inflorescência em antela simples, mais raramente composta, contraída, 5-15 (20) cm de comprimento, 6-12 (26) cm de largura, com 5-8 (14) raios primários de (5) 7-15 cm de comprimento; raios secundários, quando presentes, em média 3 para cada raio primário, de 0,5-2 (4) cm de comprimento. Brácteas involucrais (4) 5-9, a inferior 


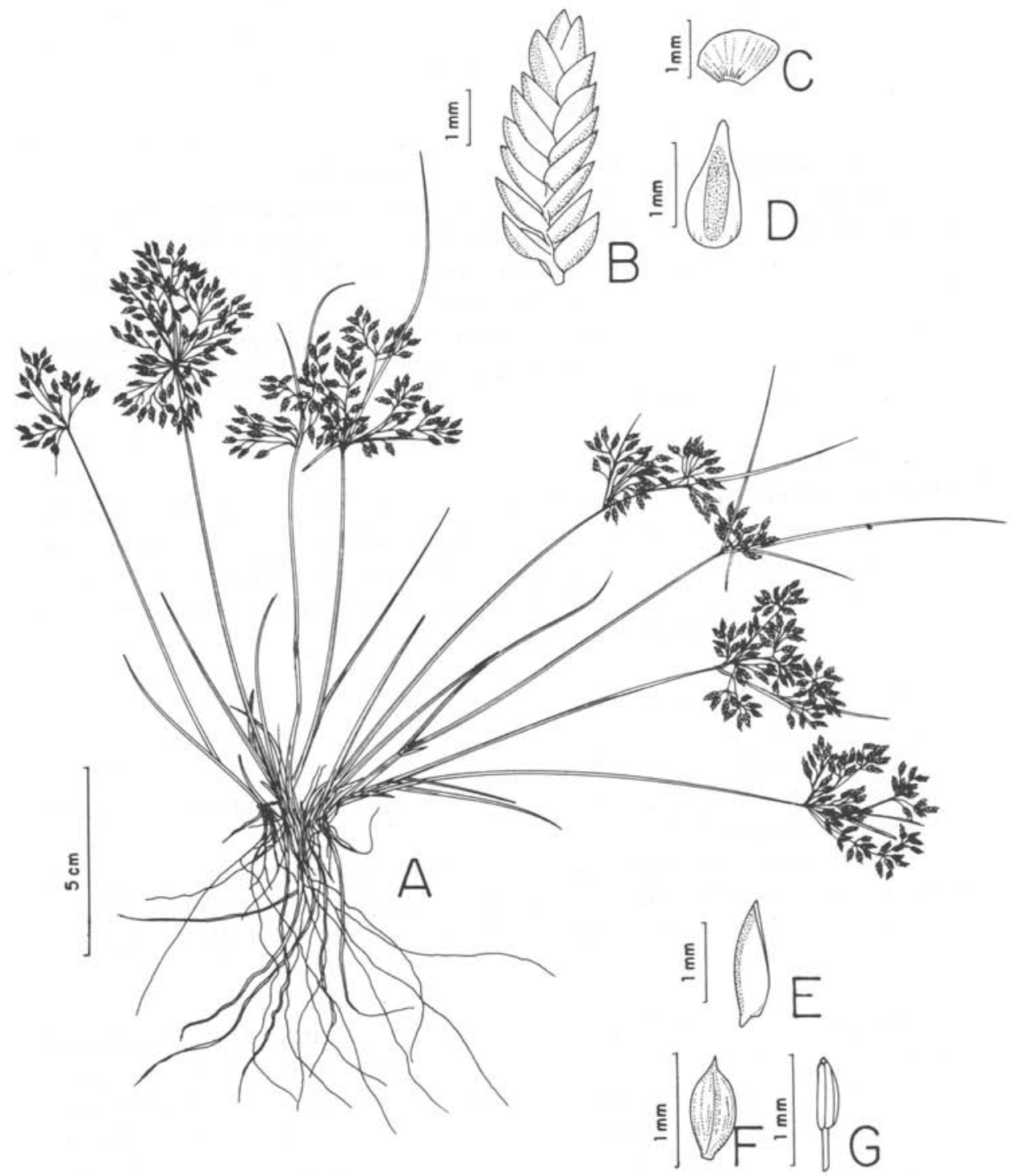

Figura 15. Cyperus surinamensis (A. G. Ferreira $174-\mathrm{ICN}$ )

A: hábito; B: espigueta, prófilo espicular e gluma bracteóide retirados; C: prófilo espicular; D: gluma bracteóide; E: gluma fértil; F: fruto; G: estame. 


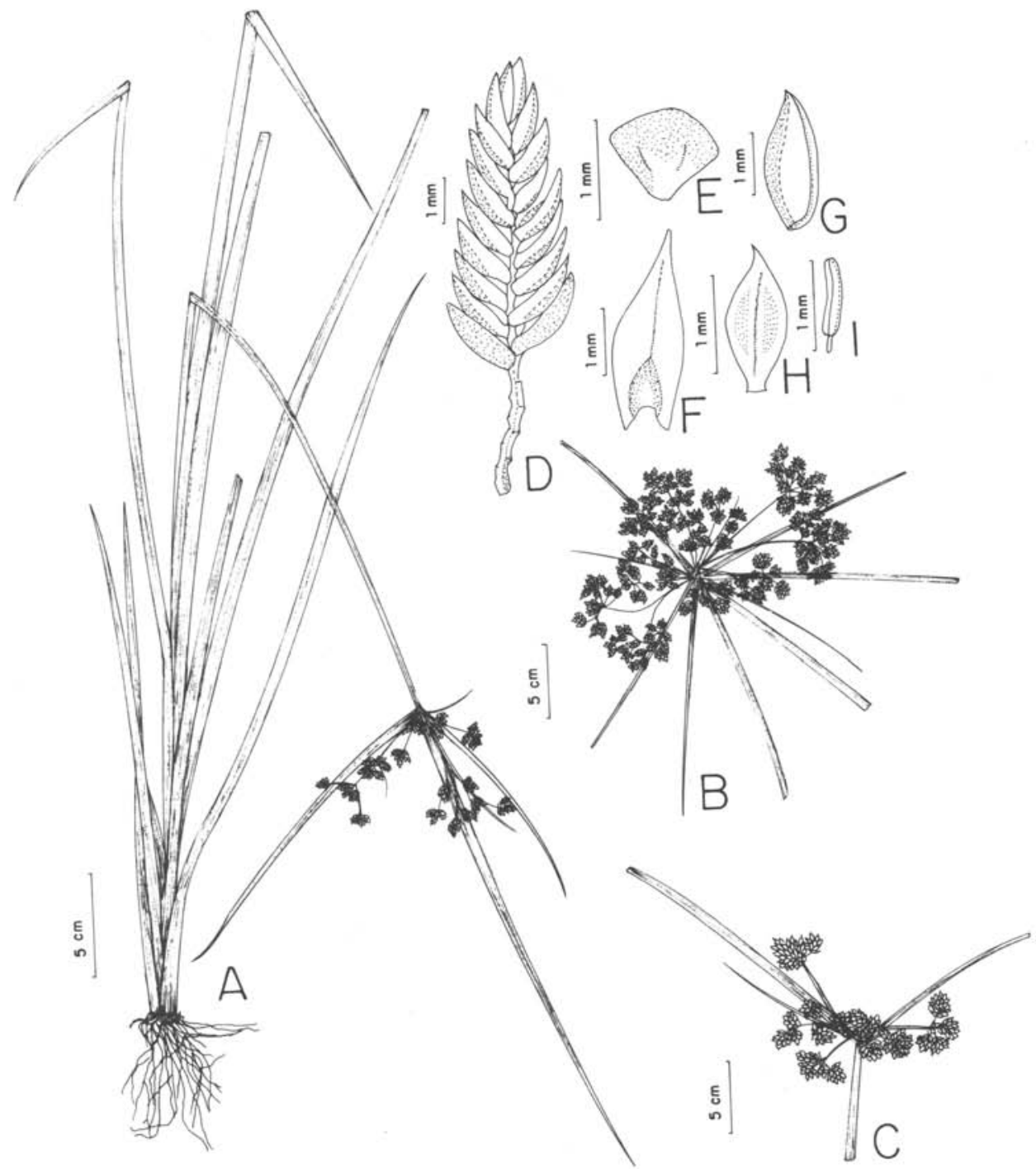

Figura 16. Cyperus virens (Longhi-Wagner \& A.C. Araujo $2245-\mathrm{ICN}$ )

A: hábito; D: espigueta, mostrando a ráquila nua, pedicelo ausente; E: prófilo espicular; F: gluma bracteóide; G: gluma fértil; H: fruto; I: estame. B: inflorescência (A.C. Araujo 22 - ICN). C: inflorescência (Longhi-Wagner \& A.C.Araujo 2291 - ICN) 


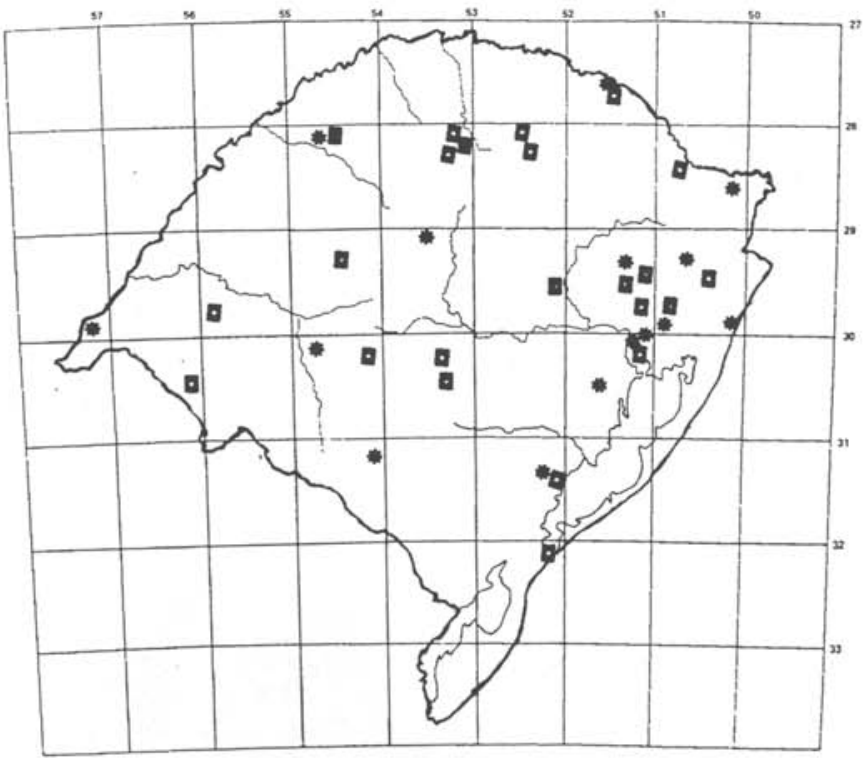

Figura 17. Distribuição das variedades de C. luzulae no Rio Grande do Sul.

C. luzulae var. luzulae ( )

C. luzulae var. entrerianius ( $*)$

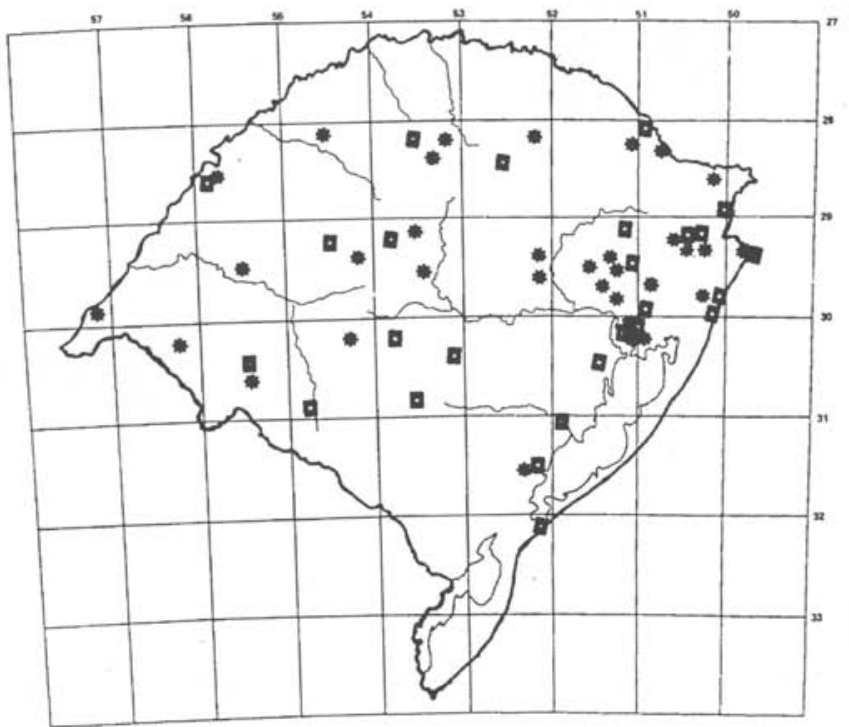

Figura 18. Distribuição das variedades de C. reflexus no Rio Grande do Sul.

C. reflexus var, reflexus ( )

C. reflexus var. fraternus (*) 


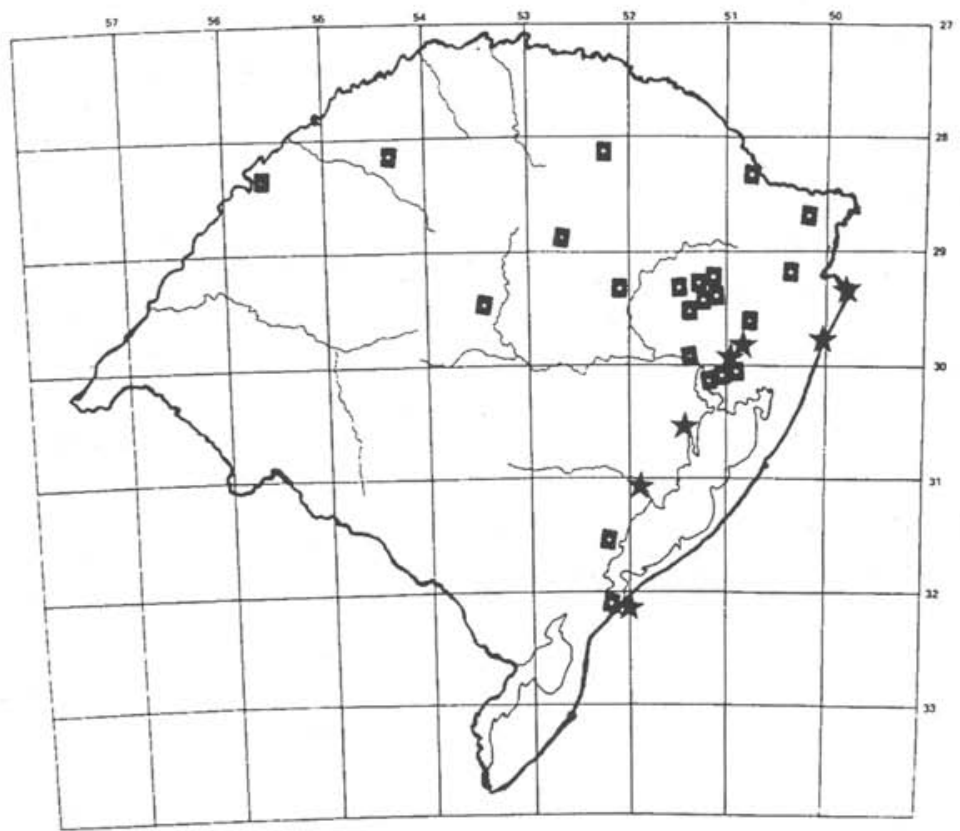

Figura 19. Distribuição de C. surinamensis ( ) e $C$. virens ( ) no Rio Grande do Sul.

$15-50 \mathrm{~cm}$ de comprimento, (4) 6-8 (12) mm de largura, escabras nas margens e nervura central, raramente com margens lisas, geralmente semelhantes às lâminas foliares, porém muito mais escabras, superfície lisa. Prófilo tubular 9- 12 (18) mm de comprimento, violáceo, ápice agudo; prófilo espicular $(0,6) 0,9-1,2(1,4) \mathrm{mm}$ de comprimento, $(0,4) 0,6-1(1,2) \mathrm{mm}$ de largura, ápice subagudo, muitas vezes deslocado lateralmente. Espiguetas 3-7 mm de comprimento, 2-4,5 $\mathrm{mm}$ de largura, as mais curtas ovadas, as mais longas lanceoladas, 5-20-floras; glumas 1,5-2,6 mm de comprimento, $(0,6) 1-1,2(1,4) \mathrm{mm}$ de largura, ovado-naviculares, ápice agudo, fortemente imbricadas, alaranjadas, às vezes avermelhadas ou esverdeadas, superfície reticulada e brilhante, carena trinervada, esverdeada, raramente amarelada, geralmente lisa, às vezes escabra nas glumas basais. Estame 1 (2), conectivo não rostrado. Aquênios 1-1,4 mm de comprimento, $(0,3)$ 0,4-0,6 mm de largura, elípticos, triangulares de faces côncavas, castanho-escuros quando maduros, superfície pontuada e brilhante, ápice simetricamente apiculado, estípete ausente.

Habitat: ocorre em banhados, campos úmidos ou alagados, beira de estrada e gramados.

Distribuição geográfica: Brasil, Argentina, Peru, Suriname e Uruguai. Foi citada também para a Colômbia, Costa Rica, El Salvador, Estados Unidos, Equador, Guatemala, Honduras, Jamaica, México, Nicarágua, Panamá, Paraguai e Venezuela. 
Fenologia: floresce e frutifica de novembro a fevereiro, tendo sido poucas vezes encontrada florescida em março ou abril. Em outros estados do Brasil há registro para os meses de maio e julho.

\section{Material examinado}

BRASIL-RIO GRANDE DO SUL: Cambará do Sul, 18 km após Tainhas, 14 dez. 1990, Longhi-Wagner, A.C. Araujo et alii 2245 (ICN); Canela, Parque Caracol, 14 jan. 1991, A.C. Araujo 21 (ICN), Cerro Largo, jan. 1943, Rambo 10866 (PACA); Farroupilha, 15 nov. 1956, O. Camargo s.n. (PACA 59365); Igrejinha, 14 jan. 1991, A.C. Araujo 23 (ICN); Passo Fundo, 9 jan. 1981, B. Severo et alii s.n. (RSPF 969); Pelotas, I.A.S., 14 nov. 1955, J.C. Sacco 413 (PEL, PKDC, R); Porto Alegre, Vila Manresa, 10 jan. 1933, C. Orth s.n. (PACA 692); Rio Grande, Estação Ecológica do Taim, 10 jul. 1986, Jarenkow 368 (PEL); Tenente Portela, Parque Estadual do Turvo, s.d., P. Brack 463, 1595 (ICN); Vacaria, Fazenda da Ronda, 4 jan. 1948, Rambo 34810 (PACA).

\section{Conclusões}

Foram encontradas 11 espécies e 3 variedades de Cyperus subg. Anosporum no Rio Grande do Sul.

Cyperus entrerianus foi aceita como variedade de C. luzulae. Cyperus haspan ssp. juncoides e C. efoliatus foram aceitas como sinônimos de $C$. haspan var. haspan. As regiões fisiográficas do Rio Grande do Sul onde ocorre o maior número de espécies de Cyperus subg. Anosporum são o Litoral e Depressão Central.

Os taxa mais comuns são C. haspan var. haspan, C. incomtus, as duas variedades de C. luzulae e C. reflexus var. reflexus..

Os taxa mais raros no Estado são $C$. celluloso-reticulatus, $C$. friburgensis e $C$. consanguineus.

\section{Referências bibliográficas}

Barros 1960. Las Ciperáceas del estado de Santa Catalina. Sellowia, v. 12, n. ${ }^{\circ} 12$, p. 181-450.

Bentham G. \& Hooker, J.D. 1883. Genera Plantarum. Londres: L. Reeve, v. 3 pte. 2.

Bertels, A. 1956. Contribuição ao conhecimento das Ciperáceas de Pelotas (RS). In: CONGRESSO NACIONAL DE BOTÂNICA, 5, 1954, Porto Alegre Anais... Porto Alegre: Sociedade Botânica do Brasil. p. 33-43.

Bertels, A. 1967. Ciperáceas no RS. In: CONGRESSO NACIONAL DE BOTÂNICA, 15, 1964, Porto Alegre. Anais... Porto Alegre: Sociedade Botânica do Brasil. p. 77-89.

Boldrini, I.I. \& Cunha, H.H.M. 1984. Contribuiçao ao reconhecimento das espécies do gênero Cyperus L. ocorrentes no municipio de Porto Alegre, Rio Grande do Sul, Brasil. Iheringia, v. 32, p. 63-75.

Clarke, C.B. 1893. Cyperaceae. In: Hooker, J.D.; C.B.; K.C.S.I. The flora of British India. Periodical Experts Book Agency, v. 4, pte. 19, p. 449-672.

Denton, M.F. 1978. A taxonomic treatment of the Luzulae group of Cyperus. Contr. Univ. Michigan Herb., v. 11, $\mathrm{n}^{0} 4$, p. 197-271.

Engler, A. 1964. Syllabus der Pflanzenfamilien. Berlin: Gebriider Borntraeger, v. 2.

Goetghebeur, P. 1989. Studies in Cyperaceae 9. Problems in the lectotypification and infrageneric taxonomy of Cyperus L. Bull. Soc. Roy: Bot. Belgique, v. 122, p. 103-114. 
Grisebach, A.H.R. 1864. Flora of the British West Indian Islands. London: Lovell Reeve.

Hohlmgren, P. et alii, 1990. Index Herbariorum. 7 T. ed Regnum Veg. 120: 1- 452.

Koyama, T. 1961. Classification of the family Cyperaceae. Journ.Fac. Sci. Univ., III, Tokyo, v. 8, n 3, p. $37-148$

Kükenthal, G. 1936. Cyperaceae Scirpoideae, Cyperus In: ENGLER, A. Das Pflanzenreich: Regni Vegetabilis Conspectus. Weinheim: H.R. Hengelmann, v. 4, $\mathrm{n}^{\circ} 20$, p. 1-621.

Kunth, 1837. Enumeratio Plantarum, Stutgart: Sumtilus y. 6. Gottal. v. 2. 359 p.

Lye, K.A. 1981. Studies in African Cyperaceae 18. Two new subgenera of Cyperus. Nord. J. Bot., v. 1, n. ${ }^{\circ}$ 1 , p. 57-61.

Mason, H.L. 1957. A Flora of the Marches of California. Berkeley, Univ. California Press, p.; 203-324.

McGivney, C.R. 1938. A revision of the subgenus Eucyperus found in the United States. Catholic Univ. Amer. Biol., der. 26, p.: 1-74.

Metcalfe, C.R. 1971. Anatomy of de Monocotyledons-Cyperaceae. Oxford: Oxford Univ. Press, v.1, n. 1, p. 111-135.

Nees, C.G. 1842. In: MARTIUS, C.F.P. Flora Brasiliensis. Monachii: Frid. Fleischer, v. 2, part 1 .

Osten, C. 1932. Las Ciperáceas del Uruguai. Anales del Museo de Historia Natural de Montevideo, Montevideo, ser. 2, t. 3.

Rambo, P.B. 1949. Flora de Cambará. Sellowia, v. 1, nº 1, p. 111-135.

Rambo, P.B. 1954. Análise histórica da flora de Porto Alegre. Sellowia, v. 6, nº, p. 9-112.

Rambo, P.B. 1956. A flora fanerogâmica dos Aparados riograndenses. Sellowia, v. 8, n 7, p. 235-98.

Rambo, P.B. 1959. Cyperaceae riograndenses. Pesquisas, Porto Alegre, v. 3, p. 353-453.

Reed, M.S. 1935. A taxonomic and floristic study of the genus Cyperus in North Carolina. Thesis submitted for the degree of Master of Arts in the Graduate School of Arts and Sciences of Duke University.

Teodoro Luiz, Ir. 1960. Flora analítica de Porto Alegre. Canoas, Instituto Geobiológico La Salle. 100 p.

Tucker, G.C. 1983. Two new species of Cyperus subgenus Protocyperus from Mexico and Central America. Bull. Torrey Bot. Club, v. 110, $\mathrm{n}^{0} 2$, p.: 161-165.

Tucker, G.C. 1985. A revision of the Mexican species of Cyperus L. (Cyperaceae). Dissertation submitted in partial fulfillment of the requirements for the degree (Doctor of Philosophy) in the Graduate School of Duke University. 1985.

Uitten , H. 1966. Flora of Suriname. Leiden: E.I, Brill, v. 1, part. 1. Reprint.

\section{Índice de Exsicatas}

OBS: O número entre parênteses corresponde ao número dos taxa, conforme citado abaixo: 1- Cyperus andreanus, 2- C. celluloso-reticulatus, 3- C. consanguineus, 4- C. eragrostis, 6- C. friburgensis, 7-C. haspan var. haspan, 8- C. haspan var. coarctatus, 9- C. incomtus, 10- C. luzulae var. luzulae, 11- C. luzulae var. entrerianus, 12- C. reflexus var. reflexus, 13- C. surinamensis, 14- C. virens.

- Abruzzi: 782 (8); 1082 (6).

- Araujo, A.C.: 1(10); 5 (10); 9 (12); 17 (11);21 (4); 23 (14); 27 (10); 28 (10); ICN 89377

(9); ICN 89378 (8).

- Arzivenco: ICN 42950 (8).

- Augusto, Ir.: 153 (4).

- Baptista, L. \& M.L. Lorscheitter: ICN 28193 (2).

- Bassan, M.: 709 (5). 
- Bertels: 450 (12); 462 (6); 463 (8); 1051 (4); 1070 (12).

- Boechat, S.: ICN 43322 (10).

- Boldrini, I.: ICN 8939 (11).

- Brack, P.: 463 (14); 1290 (3); 1374 (1); 1586 (6); 15959 14); ICN 89190 (8).

- Buselato, T.: 111 (8).

- Camargo, O.: 27 (7); 138 (3); 2568 (9); 2568a (12); 2663 (1); HAS 50955 (2); 59363 (14).

- Cristobal \& Krapovickas: 34158 (12).

- Ferreira, A.G.: 121 (9); 164 (4); 174 (13).

- Frederichs, B.: PACA 26788 (1).

- Garcés, L.: ICN 89343 (9); ICN 89357 (6).

- Irgang, B. et alii: ICN 5935 (8); ICN 28194 (3).

- Jarenkow: 368 (14).

- Jarenkow et alii: 245 (9).

- Longhi-Wagner: 2030 (11); 2033 (8); 2129 (4); 2132 (10); 2133 (10).

- Longhi-Wagner \& A.C. Araujo: 2009 (7); 2021 (13); 2062 (10); 2073 (6); 2076 (7); 2080 (7); 2085 (7); 2086 (7); 2090 (7).

- Longhi-Wagner, A.C. Araujo et alii: 2138 (10); 2158 (11); 2159 (9); 2181 (11); 2245 (14); 2269 (2); 2275 (6); 2279 (12); 2283 (11); 2299 (11); 2327 (10); 2328 (8); 2329 (8); 2332 (12); 2361 (10); 2363 (12); 2397 (11); 2345 (6); 2359 (6); 2360 (6); 2372 (9); 2387 (10); 2410 (6); 2413 (4); 2417 (9); 2420 (11); 2431 (60; 2432 (9); 2433 (11); 2506 (2); 2510 (4); 2511 (2); $2514(8)$.

- Malme: 86 (11).

- Mariath, J.: 705 (12).

- Mattos, J.: 6276 (11).

- Mattos, J. \& N. Mattos: 30591 (11).

- Mattos, J. et alii: 29015 ( 10).

- Maurman: 2996 (9).

-Nhuch: ICN 83083 (3); ICN 89017 (13); ICN 89020 ( 13); ICN 89021 (13); ICN 89022 (13).

- Orth, C.: PACA 692 (14).

- Pellizzaro et alii: ICN 21820 (1).

- Pilz, A.: 733 (6).

- Pivetta: 738 (8).

- Pott: 19 (9); 348 (10); BLA 12104 (10).

- Pott \& Valls: BLA 13374 (10).

- Rambo: 697 (6); 8885 (11); 10866 (14); 30746 (6); 34810 (14); 45221 (11); 45371 (6); 53135 (8).

- Sacco, J.C.: 412 (11); 413 (14); 803 (6); 1919 (8).

- Severo, B. et alii: RSPF 969 (14).

- Severo, B. \& R. Werlang: 516 (4); RSPF 912 (6).

- Smith, L.B. \& Klein: 8170 (8).

- Sobral, M.: 1912 (6); 2015 (8). 3230 (10); 5289 (12); 5959 (1).

- Sobral, M. et alii: 4347 (8).

- Sobral, M. \& R. Schmidt: 4132 (12).

- Zauda, R. C. Brolo: RSPF 4258 (11). 